\title{
Bevinding en geestelike verlating op die limiete: Die historiese en teologiese kontekstualisering van die pioniersvrou Hester Venter (c1750-c1830) se Ondervindelijke Bekeeringsweg
}

\author{
A W G Raath \\ Departement Staatsreg en Regsfilosofie \\ Universiteit van die Vrystaat
}

\begin{abstract}
Experiential theology and spiritual desertion on the borders: The historical and theological

contextualisation of the pioneer woman Hester

Venter's (c1750-c1830) Experiential Way to

\section{Conversion}

Theological experience is a multi-facetted reality. In experiential theology the emphasis is on the resurrection of and communion with Christ. It is the acceptance of Christ to salvation and has both internal and external dimensions. As such it has a unique position in Reformational theology. Hester Venter's Experiential Way to Conversion has significant value by illuminating the "Dopper"trekboers' puritan theology. Furthermore, it casts light on the national implications of this Reformed strand of theology at a keyphase of the "Dopper"-trekboer movement into the interior of Africa. The article argues that a contemporary value of Reformed theology is that it provides an alternative to the current growth of Eastern mysticism. Reformed pietism can serve as a legitimate theological experiment for adherents to the Reformed faith who strive to live from the faith.
\end{abstract}

\section{INLEIDING}

In 1853 verskyn die piëtistiese werk De Ondervindelijke Bekeeringsweg van die pioniersvrou Hester Venter by die drukker Van de Sandt de Villiers te Kaapstad. ${ }^{1}$ Uit die kort gedig op die titelblad skyn die rede vir die publikasie 
van haar stigtelike oordenkings geleë te wees in die troos wat gelowiges uit haar lewensloop kan put:
Al wat men hier toch lijdt is kort en ligt,
Bij d' eeuw'ge vreugd onnoemlijk van gewigt;
Elk volg deez' zaal'ge vrouw in haar geloof en wandel
Gedurig ziend' op d' uitkomst van haar handel.
God geev' ons allen een zalig uur als haar
En uit genâ zijn eeuwige rijk hiernaar.

(Venter 1853:titleblad)

Die gepubliseerde werk het nie 'n voorwoord wat verdere motivering vir die verskyning van die werk vermeld of 'n nadere kontekstualisering van die inhoud van die outobiografiese aantekeninge van die outeur gee nie. ${ }^{2}$ Die historiese en teologiese kontekstualisering van die inhoud van haar godsdienstig-bevindelike beskrywinge moet derhalwe oorwegend uit eksterne bronne en tot 'n mindere mate uit die inhoud van die Bekeeringsweg self geput word.

Die inhoud van haar godsdienstig-bevindelike diskoers is van die min teologiese literatuur uit die pen van Boerevroue uit die tydperk voor en tydens die Groot Trek. Alhoewel die werk grootliks op die godsdienstige ervarings van 'n spesifieke persoon betrekking het, werp die inhoud van haar werk waardevolle lig op die teologiese belewenisse en vertolking van vroue wat onder pioniersomstandighede die militêre, ekonomiese, sosiale en kerklike geskiedenis van 'n godsdienstige en kulturele gemeenskap-in-wording meegemaak het.

Die perspektiewe wat uit die teologiese waarnemings van hierdie vrou na vore kom, verkry besonder diepte en betekenis binne die historiese en teologiese konteks waarin sy haar geestelike ervaringe boekstaaf. Synde deel van die "Dopper"-trekboerbeweging na die binneland, bied sowel die inhoud van die werk as die kontekstualisering daarvan waardevolle perspektiewe op die historiese en teologiese onderbou van die denke van die vroue-"Doppers" wat op die voorpunt van die vroeë Boerepioniersbeweging na die binneland die impak van die oorlewingstryd op die oostelike limiete van die Kaapkolonie in die tweede helfte van die 18de eeu meegemaak het. Die persoonlike omstandighede waaronder sy as moeder en eggenoot die pionierslewe van die trekboerbeweging na die binneland meegemaak het, was alles behalwe 'n gemaklike en rustige bestaanswyse. Met min mediese geriewe moes sy aanskou hoe haar kinders ernstig siek word sonder dat sy veel daaraan kon doen. Haar gestel word self ook deur ernstige siekte aangetas. Familielede en 
vriende se afsterwe op die grense laat leemtes wat moeilik gevul kan word, sodat sy die verwerking van haar verlies selfs in digvorm verwoord. Ook die siekte en afsterwe van 'n haar eie seun is vir die pioniersgesin 'n groot verlies, sodat sy in digvorm uiting aan haar moedersmart gee. Teen die agtergrond van haar persoonlike ervaringe op die grense van die Kaapkolonie, bied haar godsdienstige waarnemings belangrike stof vir ' $n$ insig in die ontwikkeling van die piëtistiese godsdiensbelewing van die pioniersgesinne in 'n belangrike fase van die ontwikkeling van die gereformeerde denke in die tweede helfte van die 18de eeu.

\section{DIE HISTORIESE KONTEKSTUALISERING VAN HESTER VENTER SE BEKEERINGSWEG}

\subsection{Die genealogiese konteks}

Hester Venter (gedoop 1 Februarie 1750) was die derde kind van Jan Hendrik Venter (gedoop 26 Desember 1723, oorlede 1793), getroud op 7 Februarie 1745 met Maria Buys (gedoop 25 September 1725), 'n dogter van Barend Buys van Brunswyk (De Villiers \& Pama 1981:1007). Hester Venter is op 12 Oktober 1766 met Hendrik van der Walt in die huwelik bevestig. Hy was die tweede seun van Geele Andriesz van der Walt van Veenwouden, Friesland, wat op 16 November 1742 te Stellenbosch met Johanna Weyers getroud is. Sy was die dogter van Heinrich Weyers van Eppe (Duitsland) en Elizabeth Gerrits.

Hester Venter stam uit een van die bekendste gereformeerde families van die Kaap. Haar oupa, Pieter Venter (gedoop 18 Oktober 1699, oorlede omstreeks 1765; getroud op 30 November 1721 met Hester $\mathrm{Nel}^{3}$ (gedoop 1 Augustus 1706)), verteenwoordig in die tydperk 1745 tot 1759 die gemeente Swartland op die gekombineerde kerkvergadering wat in dié tydperk gepoog het om deur navolging van die Dordtse Sinode, die gereformeerde godsdiens teen die invloede van die nuwe tydsgees te beskerm (Spoelstra 1907:534). Wanneer die owerheid in 1759 die gekombineerde Kerkvergadering afskaf, begin groot getalle veeboere na die Agter Sneeuberggebied te verhuis. In die proses, skryf Spoelstra, neem hulle die "ernstige, konserwatiewe gereformeerde godsdiensopvatting" met hulle saam. Waneer die nuwe oorsese geestesstrominge die Kaapse politieke en godsdienstige denke begin beïnvloed, bewoon hulle reeds 'n geïsoleerde gebied van die Kaapkolonie (Spoelstra 1963:3).

Hester se vader, Jan Hendrik Venter, woon eers naby RiebeeckKasteel en in 1751 reeds naby die huidige Vanrhynsdorp (Mossop 1947:276). Haar oom, Jan Adriaan Venter (gebore 14 Mei 1730), getroud met Maria 


\section{Bevinding en geestelike verlating op die limiete}

Jourdan $^{4}$ en haar swaer Andriesz van der Walt (gedoop 10 November 1743, getroud te Tulbagh op 28 Februarie 1768 met Johanna Maria van der Merwe) (De Villiers \& Pama 1981:1097) was, saam met die Van der Walt-familie, van die eerste Boeretrekkers wat uit die Bokke- en Roggeveld verby die vooruitgeskuifde bevolking tot agter die Sneeuberge verhuis (Van der Merwe 1945:110). Van die Van der Walt-familie het drie verkillende gesinne vóór 1778 reeds tot in die hartjie van die destydse Boesmanland, naby die huidige Colesberg getrek (Van der Merwe 1937:23). Reeds vóór 1742, tot met sy dood in 1787, het haar skoonvader Andriesz van der Walt in die Roggeveld geboer (Van der Walt 1989:10-1). Die veeboerpioniers vanuit Stellenbosch het hulle op die kruin van die Roggeveldberg gevestig (Van der Merwe 1945:124). Vanweë die koue winters het hulle in die winter na die laerliggende Karoo getrek. Na die eerste winterreëns, so vroeg as April, maar gewoonlik tussen 15 Mei en 15 Junie, het die trek begin. Vir ongeveer vier maande het die huisgesin van die trekboer saam getrek (Van der Merwe 1945:138-9). 'n Klompie huisgesinne het in groepies van vyftien tot twintig waens bymekaar gestaan, by wat as 'n "legplek" - 'n tydelike staanplek waarheen die trekboere gereeld teruggekeer het - gestaan (Van der Merwe 1945:114). Die feit dat haar skoonvader weiregte op die Roggeveldberge asook in die Karoo gehad het, bevestig dat hy en sy gesin ook aan die wintertrek deelgeneem het (Van der Walt 1989:11). Dit was omstandighede waaronder Andriesz van der Walt en sy gesin vir 'n deel van die jaar geleef het (Van der Walt 1989:11).

Op 12 Oktober 1766 tree Hendrik van der Walt met die sewentienjarige Hester Venter in die huwelik (Van der Walt 1989:21). Op 28 Februarie 1768, by dieselfde geleentheid waarop twee van sy broers en een van sy susters op Tulbagh in die huwelik tree, word hulle eerste dogter, Johanna Maria, gedoop (KKA, G4 3/2:9). In dieselfde jaar word die plaas Doornberg aan die Zeekoeirivier aan hom toegeken (KAB, RLR 20:141). Daar het hy tot in 1787 weiregte gehad (KAB, RLR 35:196). Op 16 Oktober 1771 word weiregte op Ezelsfontein in die Roggeveld aan hom toegestaan (KAB, RLR 21:311). Die vorige eienaar van die plaas was sy swaer Jan Albert Venter, wat met Anna Maria van der Walt (gebore 1752) getroud is (Van der Walt 1989:21). Op 24 Maart 1772 ontvang Hendrik van der Walt ook weiregte op die plaas Rietfontein op die Sneeuberg (KAB, RLR 22:92). ${ }^{5}$ Sy weiregte op Rietfontein het in 1781 verval. Intussen is weiregte op die plase Olyfenhoutsfontein "gelegen aan deeze zeide van de Zondagsrivier" (KAB, RLR 78a:159, 193), asook "de Draaijhoek agter de Zondagsrivier" (KAB, RLR 78a:159, 361), en "de van Aardskraal gelegen over de Bruinshoogte aan de Groote Visch Rivier" aan hom toegeken (KAB, RLR 78a:159, 202). Op 29 Maart 1783 word "Tweefonteijnen agter de Renocer bergen" ook aan hom toegeken (KAB, RLR 
78a:193). Op 16 Oktober 1795 word weiregte op Caroluspoort langs die Zeekoeirivier aan hom toegestaan (Van der Walt 1989:22).

Reeds teen die einde van 1779 trek drie van die Walt's saam met 'n paar ander boere uit die Sneeuberg na Renosterberg, in die hartjie van Boesmanland, waar hulle al voorheen 'n keer gewoon het. Die rede was, volgens hulle verklaring, dat hulle dit as gevolg van die stelery van die Boesmans nie langer in die berge kon uithou nie. ${ }^{6}$ By Renosterberg was die weiveld goed en dit was oop wêreld, waar daar minder skuilplekke vir die Boesmans was. Vanweë die nomadiese lewe wat die familiegroepe in die binneland gevoer het, het hulle nie vir lang tydperke op dieselfde plek gevestig nie. Teen 1803 bewoon die welgestelde kommandant Johannes van der Walt ${ }^{7}$ nog 'n "rampzalige hut van riet" (Molsbergen IV:197). ${ }^{8}$ In dieselfde jaar bevind die weduwee van kommandant Tjaart van der Walt, die swaer van Hester Venter, haar reeds oos van Graaff-Reinet. Waarskynlik was die familie toe op trek na die latere Steynsburg-distrik (Molsbergen IV:186-190).

Ongeveer dieselfde tyd reis saam met veldkornet Jacob Venter (gedoop 4 Februarie 1784, burger van Graaff-Reinet, getroud op 9 Oktober 1800 met Maria Magdalena Sophia Pretorius), 'n broerskind, goewerneur Janssens noordwaarts verby Renosterberg, Tafelberg en Caroluspoort na Van der Waltsfontein, naby Plettenbergsbaken, aan die Seekoeirivier. Hier ontmoet hulle onder andere haar broer Piet Venter en Nicolaas van der Walt, 'n swaer (gedoop 13 Februarie 1757, getroud met Maria Jacoba Coetsee). Haar swaer, kommandant Johannes van der Walt (gebore 7 Oktober 1749) (Van der Walt, 1989:43), het onder andere die plase Wolwekop, Caroluspoort en Van der Waltsfontein besit (Molsbergen IV:186-190). Teen 1809 was hy steeds aan die Seekoeirivier woonagtig (Van der Merwe 1937:114).

Reeds in die tydperk tussen 1770 en 1800 het familiegroepe soos Van der Walt, Venter en Kruger hulle in die gebied noord van die Sneeuberge bevind (Spoelstra 1963:19). Deur ondertrouing is hierdie families nog hegter saamgebind. John Murray skryf in 1877 soos volg oor die rol van die families Venter en Van der Walt in dié gebied:

The prominent family names were Van der Walt, Kruger, Venter and Coetzee. The Van der Walts might in some respects be considered the aristocracy of the district; they were lineal or collateral descendents of the famous Tjaart van der Walt ... Gradually they developed the peculiarities which have won for them their distinguishing epithet. Living in secluded districts, clinging to old fashions and habits, inter-marrying only among near neighbours and relatives, a clannish spirit was formed separating them not 


\section{Bevinding en geestelike verlating op die limiete}

merely from the English settler of later date but even from their own fellow-countrymen.

(Murray 1877)

Die treklewe het die verdienste aan 'n standhoudende inkomste moeilik gemaak. Voorts was daar nie veel geleenthede vir die kinders om formele skoolonderrig te ontvang nie. Hester Venter skryf dat haar ouers arm was (Venter 1853:3). Toe sy twaalf jaar oud was, is sy onder die sorg van haar moeder se suster ("mijne moeije") geplaas, waar sy vir drie maande skoolonderrig ontvang het (Venter 1853:3). Ná haar terugkeer na haar ouerhuis, het sy dit deur middel van selfoefening en die onderrig van haar moeder sover gebring dat sy kon lees en skryf. Volgens haar mededelings het sy en haar man, Hendrik, "een goed bestaan" gevoer, as gevolg van die erfenis wat beide sy ouers nagelaat het (Venter 1853:4). Op dertigjarige ouderdom het haar weduwee-moeder haar ontval en moes die erflating onder ses dogters en drie broers verdeel word (Venter 1853:4).

Die gemeenskaplike lotsverbondenheid van die Dopper-trekboere in afsondering op die limiete van die Kaapse oosgrens het 'n eie godsdienstige tipe tot gevolg gehad. Waar die loslating van die gereformeerde belydenis deur die Nederlandse staatskerk in die tweede helfte van die 18de eeu, teologies tot 'n meer verstandelike rigting gelei het, het die pioniers op die Kaapse voorposte aan die teologiese opvattings van die outeurs van die Nadere Reformasie verkleefd gebly. Die verskynsel dat die trekboere hulle in familiegroepe georganiseer het, moes 'n beduidende rol gespeel het om 'n gereformeerde tipe tot stand te bring wat in hulle armoede en afsondering die teologiese standpunte wat in hulle geledere werksaam was, te versterk (kyk Raath 2002:47). Die swak ekonomiese bestaan op die oostelike limiete, tesame met die daaglikse oorlewingstryd het 'n ongekunstelde "nomadiese teologie", binne die konteks van die Nadere Reformasie, gekweek wat in vele opsigte in hulle daaglikse lewensstryd tot uiting gekom het (kyk Raath 2002:50-51).

\subsection{Hester Venter se Bekeeringsweg binne die konteks van die konflik op die oosgrens}

Soos aangedui, het die familiegroepe waarin Hester Venter haar in die loop van die 18de eeu bevind het, deel van die trekboerbeweging na die noorde van die Kaapprovinsie gevorm. As gevolg van die uitbreiding van die veeboerdery het die trekbeweging na die binneland ná 1700 sterk toegeneem (Van der Merwe 1937:1). Reeds in die veertigerjare van die 1700's swaai die emigrasiebeweging, wat oorspronklik noordwaarts beweeg het, na die ooste 
om. Uit die Bokkeveld trek die koloniste deur die Karoo tot in die Roggeveld (Van der Merwe 1937:2). Op die noordoosgrens kom die trekboere in direkte kontak met die Boesmans. In die streek agter die Hexrivier tot aan die Swartberge, uit die Roggeveld, die Koup, die Sneeuberge en die Camdebo word deur die Boemans "plaatsen afgeloopen, de huijsen verbrand en vernield" en deur die Boesmans ingeneem (KAB, St. 229). ${ }^{9}$ Die voortdurende Boesmanaanvalle en rowery het tot gevolg gehad dat burgerkommando's deurlopend in die veld moes bly, sodat 'n versoekskrif uit Graaff-Reinet, gedateer 1 Februarie 1788, in 'n toon van mismoedigheid vermeld dat "om welke rede ook al veele van ons uijt misnoeghijt de moet verlooren uijt 't veld getrokken zijn, ook wel de eerstijts strijtbare mannen zijn geweest, die men niet gerne hadden willen missen, maer men bekomt van hun ten antwoord al moeten ze haar leeftijt om zwerven en dolen zonder verblijf te kunnen vinden het egter niet schadelijker of onrustiger kan sijn als hier" (KAB, C. 321:453). Die toestand het in die negentigerjare van die 18de eeu voortgeduur. Op 9 Februarie 1792 rapporteer die landdros van Graaff-Reinet, M H O Woeke, byvoorbeeld "dat de gem. Natie thans horribel te keer gaat en overal mat Troupen onder d' Ingesetenen indringen; en niet tegenstaande de gedurige commandos is er bijna geen contrije van deselve bevreijd, waar dezelve niet steelen, rooven en moorden (Van der Merwe 1937:17). Plase is helder oordag aangeval, mense is vermoor, geboue afgebrand en troppe vee weggedryf (Van der Merwe 1937:17). ${ }^{10}$

Die boere in die Sneeuberge het egter met vasberadenheid die stryd teen die Boesmans volgehou. "The people of Sneeuwberg, lying nearest to the common enemy," skryf Barrow, "were left to sustain the whole brunt of the business; and had they not conducted themselves with great fortitude, perseverence, and address, that valuable part of the Colony, the nursery of cattle, had now been abandoned" (Barrow I 1806:235). Van die onveiligheid wat die inwoners van die gebied moes trotseer, skryf Barrow:

An inhabitant of Sneeuwberg has not only the continual apprehension of losing his property, but he lives in a state of perpetaul danger. Should he depart to the distance of five hundred yards from his house, he is under the necessity of carrying a musquet. He can neither plough, nor sow, nor reap, without his arms. If he would gather a few greens in his garden, he must take his gun in his hand. To bear a life of such constant dread and anxiety, a man must be accustomed to it from his infancy, or unaquainted with one that is better.

(Barrow 1806:249) 


\section{Bevinding en geestelike verlating op die limiete}

Ook verhoudinge tussen die grensboere en die swartstamme aan die oosgrens was gespanne. In 1779 is die swartes met geweld oor die Visrivier gedryf. Die verhoudinge tussen die Boere en die swartes het egter gespanne gebly, sodat 'n tweede oorlog in 1793 uitgebreek het (Van der Merwe 1940:5). In Mei van dié jaar het sake aan die oosgrens 'n ernstige wending geneem. Etlike gesinne was verplig om van die oosgrens te vlug omdat hulle dit nie langer daar kon uithou nie. Dié wat agtergebly het, het bymekaar getrek sodat hulle mekaar kon help. Nadat hulp deur heemraad Petrus Hendrik Ferreira uit Swellendam gebied is, kon enigsins weerstand gebied word (Van der Merwe 1940:30).

$\mathrm{Na}$ aanleiding van die feit "dat het land in een beroerte en opstand was" - verwysend waarskynlik na een van die Boesmaninvalle in die 1790's skryf Hester Venter hoe sy "bedroefd met vreeze tot den Heere deed vlugten, met smeekende gebeden, ootmoedig roepende tot God om genade en behoudenis, voor kerk en land" (Venter 1853:47). Teenoor diegene wat saam met haar in die huis was, kon sy nie nalaat om haar dank vir hulle redding te besing nie; "zoo juichende in den Heere, dat ik het niet houden kon, maar sprak vol van liefde en vertrouwen op den Heere, ... dat niets was voorgevallen; o hoe goed is God over zijn volk dat Hem vreest en in nederigheid zijn aangezicht zoekt ..." (Venter 1853:47). Sy volg dit op met 'n gedig waarin sy die aanslag primêr as 'n aanval teen die strydende kerk beskou:

Die groote God, dat sterke schild, Die onzer nog ontfermen wilt, Maar gij, o boozen, volk met magt, Die stelt gij zoo in eigen kracht, Die God die ons beschermen kan, Daar wijkt gij zoo gedurig van, En werkt zoo door uw eigen kracht, En stelt den vijand tot uw magt, Zijn raadslag zal te niete gaan, Gods kerke zal ook blijven staan, O strijdend kerke die hier zucht, Al schreijend nemende haar toevlugt, Zoo tot den hoogen Opperheer Die alles naar zijn wil regeer!

(Venter 1853:47)

Elders skryf sy dat "was in het land in groote beroeringe, zoo riep ik den Heere aan uit benaauwdheid mijns harten" (Venter 1853:50). Sy vind genade in Gods oë en word versterk met die teks uit Jesaja 63:1: "Wie is dit wat daar 
aankom uit Edom, met bloedrooi klere uit Bosra? Hy daar, pragtig in sy gewaad, wat agteroor buig in die volheid van sy krag? Ek is dit wat in geregtigheid spreek, wat magtig is om te verlos." Hierdie opmerkings verwys klaarblyklik na die eerste Britse besetting van die Kaap in 1795. Sy vind berusting in die almag en geregtigheid van God:

De Heere, de Almagtige is Koning, God regeert, die heerscht in alle eeuwigheid, Heer der Heirscharen, is zijn naam, wonderlijk, raad, sterke God! Vader in der eeuwigheid! Vredevorst! God is groot, Hem zij de kracht, de eere en de heerlijkheid tot in alle eeuwigheid ... (de) Zoon Gods, medelijdende Hoogeprieser, die zijn bedrukt volk verhoort.

(Venter 1853:50)

Tydens die derde grensoorlog, 1798/9-1802, is die Boerepioniers swaar deur die invalle van die Hottentotte en Xosas beproef. Oor die aanslag van die Boesmans teen die Boere-pioniers in 1802, skryf sy 'n gedig onder die titel "Op de inlandsche vervolging der heidenen tegen het Christenrijk, de wonderbare verlossing des Heeren, 1802" (Venter 1853:134-5). Die wese van hierdie aanslag vertolk sy as 'n veldtog teen die Christendom:

O Afrika denk aan de dagen vol ellenden, Wij wisten niet ons her- of derwaarts te wenden, 't Afgodisch heidendom stormde ons land met benden, De wreede vijand op ons gangen loert, Het heele land benaauwt en beroert, Het heidendom met oogen, ooren open, Het Christendom met booze list bekropen; ..."

(Venter 1853:134-5)

En

De krijgsman, troepen, burgeren, al met een,

De heidenen heel verwoed,

Met trots en wrevel moed,

Zij leiden 't op de Duitschers toe,

En namen groote buit,

Zij traden met hun voet,

Met hoogmoeds dartle list,

En moordden in en uit,

Zij loerden op der Christenen bloed,

Hoe menig vrouw, onweerbaar maagdelijn,

Onnoozele zuigeling omgebragt,

Verwoed, vernield, door boos fenijn, 


\section{Bevinding en geestelike verlating op die limiete}

o Droeve dood! o jammer treurgeklag!"

Die burgers seëvier, alhoewel van hulle ook in die aanslag omkom:

"Door al het moord gerucht,

De Duitschers op de vlugt,

Maar ziet de Heere regeert,

De heidenen getucht,

Het kwaad werd afgeweerd.

De krijgsman als een held, Met dapperen moed en zin,

De heidenen neêrgeveld,

Werd in den slag gewond,

En schoot zijn leven in.

(Venter 1853:135)

Die Boesmaninvalle en die militêre optrede van die grensboere het vir Hester Venter en die Van der Walt-familie groot ontberinge en swaar beproewinge meegebring. Op 12 Januarie 1798 word haar seun Andries deur Boesmans in "een spelonk bij eenen steenen krans", saam met nog 'n Boer, onverwags deur die Boesmans omsingel en vermoor (Venter 1853:96). Onverbloemd kom haar moedersmart oor die familie se verlies in twee gedigte na vore:

O Zware druk, o droeve banden,

Daar ligt mijn dierbaar kind!

Verwoed vernield, door wreedaards handen,

Mijn lieve zoon door mij zoo teêr bemind.

Hij die zoo naauw ligt aan mijn hart,

O Zware druk, o tranen, smart!

(Venter 1853:96)

Het teedere moeders hart bezwijk!

Zie hier haar zoon, hij is een lijk.

O Droeve rouw, o smartelijk verlies,

Zoo schielijk weggeraapt, o bange nood!

Door monster list gewond ter dood,

Mijn waarde zoon, mijn lieve kind!

(Venter 1853:96)

In 'n vervolg op dié gedig, skryf sy:

1. O Zware druk, o droeve banden,

Gewond ter dood door wreedaards handen,

Mijn waarde zoon door mij bemind,

Verwoed, vernield mijn lieve kind,

Die mij zoo na ligt aan het harte, 
o Droeve rouw, o tranen smarte, Het teeder moeder hart bezwijk, Zie uw zoon, hij is een lijk!

(Venter 1853:98)

Tog put sy besondere troos uit die vrye genade en liefde van die Here:

6. Groot en veel zijn Gods weldaden, Goedertierene genaden, Loof en prijs met mij te zaam, Loof met mij Gods grooten naam, Kon de Heer vol liefde naschreijen, Dat hij hem na korte lijen, Hem uit vrije genade schenkt, Aan zijn zonden niet gedenkt.

(Venter 1853:99)

7. Vlammende liefde, minne stralen, Brandend in mijn harte dalen, o Wat liefde, vreugde stond! Gods min vervulde hart en mond, In Jezus bloede leeft hij veilig, Loven, heilig! heilig! heilig! Geen moeite, krijg of ongeval, In eeuwigheid hem treffen zal!

(Venter 1853:99-100)

Haar hulp soek sy by die Here alleen:

11. Trouwe herder, hoe genadig! Zaagt gij op mij, gansch onwaardig, Die in tranen neder zijgt, Aan uw voeten hangen blijft. Heer, uw wonderlijke bewaring, Als mijn ziel in druk, bezwaring, Lijd in droef heid, overstulpt, Trooste mij uwe godlijke hulp.

(Venter 1853:100)

Vier jaar later, op 23 Januarie 1802, het 'n kommando Swellendammers onder leiding van haar swaer, Tjaart van der Walt, teen die Hottentotbendes uitgetrek (KAB, BO 24:701-4). Tydens 'n geveg naby die Sondagsrivier, op 13 Februarie 1802, sneuwel Tjaart se 22-jarige seun en naamgenoot in die geveg (Van der Walt 1989:32). In Maart 1802 het die Hottentotte weer 


\section{Bevinding en geestelike verlating op die limiete}

strooptogte in die oostelike dele van die distrik Swellendam onderneem, met die gevolg dat die koloniste weer moes saamtrek of die wyk moes neem. Op 31 Mei 1802 trek Tjaart met sy kommando uit en twee weke later sluit die Graaff-Reinetters onder kommandant Hendrik van Rensburg by hulle aan (Marais 1975:319). Op 2 Augustus kom Tjaart en sy afdeling op 'n deel van die bende wat drie lede van die Scheepers-familie vermoor het af. Die bende van sewentien Xhosas en tien Hottentotte word uitgewis (Van der Walt 1989:36). Op 8 Augustus word die kraal van die res van die bende, geleë tussen die Baviaanskloof en Kouga, in die vroeë oggendure omsingel. In stryd met Tjaart se opdrag word vóór dagbreek al op die kraal geskiet. Tjaart word deur 'n vyandelike koeël getref en 'n broerskind, Andries van der Walt, swaar gewond en sy geweer afgevat (KAB, BO 24:784). In 'n rapport van kommandant $\mathrm{R} B$ Botha aan die goewerneur, op 12 Augustus 1802, word in verband met die dood van Tjaart verklaar dat "dog tot onse leerwese in die slag onse commandant Tjaart van der Walt sijn leven moete late, dog blijve in die vetrouwe dat wij door des Heere hulp onse vijand sal moge oorwinne wijl sij ons de nekke toe ken" (KAB, BO 24:773).

Die verlies van haar swaer, ${ }^{11}$ beweeg Hester Venter om 'n gedig oor sy dood te maak:

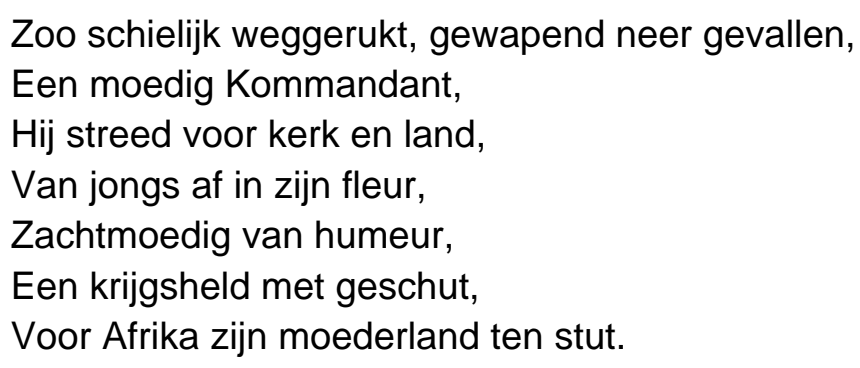

(Venter 1853:136)

Waarskynlik ook met verwysing na die derde grensoorlog en die angs wat die vyandelike aanvalle meegebring het, skryf sy 'n gedig waarin sy die soewereine beskikking van God, ten spyte van die angsvolle omstandighede waaronder die grensboere hul bevind, uitdruk:

1. O volkeren, land, denk aan de dagen, Het land beroerd met angst bezwaard,

De booze vijands list en lagen,

Spant aan op Christus schaar.

Maar 't is om onze zonden,

Dat het land getuchtigd wordt, Onze etterbuil en wonden,

Dat ons nu beangstigd maakt. 
2. 't Volk dat liep met heele benden,

Bruischend op de Christenen aan,

Van rondom, vol ellende,

Het moord gespuis sprong op de baan,

Om de Christenen te benaauwen,

Spant zij list en raadslag aan,

Op haar afgods magt vertrouwen,

Liet ze in gebreken staan.

3. Maar onze God is in den hemel,

Aard en hemel schiep hij uit niet,

Al wat zich beroert, bewemelt,

In zijn heerschappij gebied,

Liep het volk met heele benden,

Tegen ons ten oorlog aan,

God is magtig ons te wenden,

Met een wenk ter neêr te slaan.

(Venter 1853:136)

In haar Bekeeringsweg word die militêre aanslae wat die grensboere te verduur gehad het, hoofsaaklik op 'n geestelike vlak in haar digwerk behandel. Die oorheersende gedagtes wat in die gedigte wat daaroor handel na vore kom, is 'n besef van die strafwaardigheid van die grensboere en die almag van God wat alles ten goede kan laat keer.

\section{HESTER VENTER SE BEKEERINGSWEG BINNE DIE KONTEKS VAN DIE TEOLOGIESE EN KERKLIKE LEWE VAN DIE GRENSBOER-PIONIERS}

\subsection{Die kerklike lewe op die voorposte}

Die verhuising van die trekker-pioniers het op 'n belangrike tydstip van die ontwikkeling van die teologiese en wetenskaplike denke in Europa plaasgevind. Die 18de eeu was 'n oorgangsperiode wat in bepaalde opsigte kragte opgewek het wat lynreg teenoor die gereformeerde leer en kerkpraktyk te staan gekom het (Spoelstra 1963:3). ${ }^{12}$ Hoewel die Kaapse kerkstrukture nie sterk genoeg was om effektief teen die opkoms van die teologies-verligte denke uit Europa weerstand te bied nie, het dit nie in die afgeleë gebiede van die binneland gebeur nie, omdat die isolasie die trekboere teen die nuwe denkrigtings van die "verligting" beskerm het. "Daar", skryf Spoelstra, "waar alle geleenthede vir 'verligting' ontbreek het, is die gereformeerde erns van die 17de en 18de eeue streng van ouer op kind oorgedra en ingeprent" (Venter 1853:3). 


\section{Bevinding en geestelike verlating op die limiete}

Die losse organisasie van die kerke en groot afstande het die binnelandse trekboere van die burgerlike regering, die hoofstad en die gemeentes geïsoleer. Die trekboere kon hoogstens 'n enkele keer per jaar vir nagmaals- of doopbediening die kerk besoek. Origens was die trekboerpioniers op die onderlinge familieverkeer en "godsdienstige selfonderhouding" aangewys (Spoelstra 1963:5). Hierdie isolasie is eers omstreeks 1830 met die stigting van Colesberg as kerksetel opgehef (Spoelstra 1963:5). Tot die einde van die 18de eeu was Tulbagh die naaste kerkpos vir die boere van die noordelike en noordoostelike grensdistrikte. Vanweë lang afstande kon die boere die kerk nie gereeld besoek nie. In die jaar 1778 kla die boere van die Camdebo oor die agteruitgang van die godsdiens in die buitedistrikte (Van der Merwe 1938:242). Die belangrikste beswaar was dat daar nie onderwysers en predikante was nie, "soo dat een groot gedeelte van die frische jeugd op groeijen, gelijk het stomme vee, (en wij) geen geleegendheijd kennen bekomen, den jongeren te leeren de eerste beginselen, naa den ijs haaren wegs, op dat als sy oud geworden sijnde, daarvan niet moogen afwijken" (KAB, C:311). Ook die seun van goewerneur Hendrik Swellengrebel, bemerk 'n tendens tot sosiale agteruitgang onder die trekboere vir sover hulle "in een swervend veldleven door werkeloosheid tot indolentie vervallen, en hier mede alle sociale deugden verliesen" (Van der Merwe 1938:213).

Ten spyte van die gebrek aan algemene leesmateriaal op die platteland, het bykans elke Boerefamilie 'n Bybel besit. Naas die tipiese Statebybels van die tyd, kon in die meeste pioniershuise die liederebundel van Willem Sluiter, die Heidelbergse Kategismus en die Kortbegrip van Hellenbroek gevind word. Preekbundels soos die werk Donderslag der Godloozen, wat preke met aantekeninge bevat het, het die basis van die godsdienstige onderrig van die veeboer-pioniers gevorm (Van der Merwe 1938:248). Vanweë die skaarste aan kerke en predikante gedurende die 18de eeu, was die kerklike bearbeiding nie baie vrugbaar nie. Ten spyte van die behoeftes in dié verband, val die erns van die Boere se piëtistiese godsdienssin en opregte vrome lewenswandel menige reisiger op. W von Meyer skryf in 1841:

Es ist zu bewundern - wie sehr sich der Afrikanische Bauer zum Pietismus hin neigt, da er doch ganz sich selbst überlassen ist, wenig Unterricht genossen hat und selten geistlichen Herten zu Gezicht bekommt. Es giebt sicher kein Volk auf der Welt welches so wahrhaft gottesfrüchtig ist, als die Afrikaner. 
With much truth we may describe the inhabitants of the Cape Colony at large as a serious and religious people, and especially with reference to that portion forming the most considerable part of the Community, the Dutch Boers, who are deeply imbued with strong sentiments of genuine piety, and are consistent members of the Christian Church.

Die afgesonderde en vrome lewenswyse van die Dopper-pioniers, het egter ook minder positiewe indrukke by andere opgewek. In Het Volksblad van 10 September 1857 word die geneigdheid tot afgesonderde bevindelike bepeinsing die oorheersende indrukke van die godsdienstige lewenshouding van die afgesonderde Dopper-pioniers:"Niets doende, houden zij zich onledig met zichzelven te bespieden ... en zich verliezende in eenen maalstroom van verwachtingen, twijfelmoedigheden, zwartgalligheden", wagtende "op wonderbare invloeden van omhoog (droomen, gezigten, invallende schriftuurplaatsen)" (Het Volksblad, 10.9.1857).

Die werklikheid van godsdienstige afsondering, tesame met die moeilike lewe op die noordoostelike grense, het 'n besonder vrugbare aarde vir die ontwikkeling van 'n gereformeerd-piëtistiese pioniersteologie gebied. Die oorplanting van die piëtistiese teologiese literatuur vanuit Nederland het 'n besonder intense vroomheidsinslag tot gevolg gehad. Die Nederlandse skrywer Fred van Lieburg se waardevolle werk ter tipering van die piëtistiese teologiese kultuur van dié tyd, bied 'n handige invalshoek vir die verstaan van die teologiese "psige" van die vroomheidsdenke binne die piëtistiese kringe op die voorposte in die tweede helfte van die 18de eeu en die eerste helfte van die 19de eeu. Van Lieburg bespeur in die vroomheidsdenke van die tyd ' $n$ geneigdheid tot self-geringskatting in die lig van die vroomheidseise van die Skrif (Van Lieburg 1991:84-5); 'n sensitiwiteit vir die oordeel van vromes (Van Lieburg 1991:85-7); 'n beheptheid oor sekerheid van geloof (Van Lieburg 1991:87-90); 'n eie partikuliere lewensstyl en lewenshouding (Van Lieburg 1991:90-3); 'n verdieping in die vroomheidsliteratuur van die outeurs van die Nadere Reformasie (Van Lieburg 1991:93-6); 'n lewe gewy aan 'n stryd teen die Satan (Van Lieburg 1991:96-8); 'n geneigdheid tot afsondering en eensame oorpeinsing (Van Lieburg 1991:98) en 'n diepe interesse in die dood en die lewe na die dood (Van Lieburg 1991:100). Die kenmerke van die gereformeerde piëtisme deur Van Lieburg aangedui, kom ook sterk in Hester Venter se Bekeeringsweg na vore. In die geval van Hester Venter kom daar ook periodieke ervarings van geestelike verlating voor. 


\title{
3.2 Hester Venter se Bekeeringsweg binne die konteks van die gereformeerde piëtisme / vroomheidsdenke van die tyd
}

\subsection{1 "(D)en Heere grootmaken met wegzinken in zelfs nietigheid en kleinheid ..."}

Die inslag van die Bekeeringsweg kan as 'n deurlopende geringskatting en onwaardigheids-beoordeling van die gelowige voor die aangesig van God beskryf word. Telkens wanneer Hester in die dale van geestelike neerslagtigheid verkeer, dring die besef van die almag, grootheid en allesoorheersende heerlikheid van God tot haar bewussyn deur. Na 'n sterk ervaring van onwaarde en worsteling om die genade van die Here te ervaar, is die grootheid en soewereiniteit van God die anker waaraan sy vashou:

\begin{abstract}
Mijn God, stier mijne gangen, leid mij in uwe waarheid, hooge God, majesteit, die in de donkerheid woont; ik onwaardige stof en asch, de invloed uwes Geestes verlevendige het hart, doe mij, onwaardige, stamelende u navolgen, mijn liefdragende borg, Godmensch, om uwe genade smelt ik aan uwe voeten, goedertierene God, o volheid der genade, o zuivere sprinkader, heilvloeijende wateren, enge poorte, zuivere weg, genade weg, voortvloeijende uit Christus kruis; grootmagtig God, die een ontoeganklijk licht bewoont ..."
\end{abstract}

(Venter 1853:72)

Sondebesef dwing haar om uit te roep: "(J)a, moedernaakt, uitgestroopt; het is bij mij buiten hopen, tot der helle toe gedoemd; maar mij, de allergrootste zondares, is deze genade geschied; de Heer werd mij te magtig door zijns Geestes werk, zoo krachtig in Jezus zegepralende heil ..." (Venter 1853:73). Na swaar geestelike worstelinge oor haar geloof, wend sy haar "(d)ood in zonden en misdaden, tot den Heere vlugtende ..." en vind sy troos in "God, o fontein des heils, souverein, de goddelijke bron, liefdevloeijende volheid der genade; hoe dierbaar is uwe goedertierenheid, o weergalooze rijkdom ..." (Venter 1853:81). In sondebesef wend sy haar tot Christus: "o Heere, ik onwaardige, van mij zelve niets waardig, ten zij uwe goedertierene genade lielde mijwaarts, wat zal ik u vergelden Heere, ik, een behoeftige, die gedurig naar U dorst, lieve Jezus, mijn overste Leidsman, trouwe Herder ..." (Venter 1853:65).

Reeds as kind het sy haar spel met haar maats onderbreek om met besef van skuld en doemwaardigheid in afsondering te bid: "Dan schenen mijne zonden mij zoo groot te zijn, dat ik dacht, als ik sterf dan moet ik naar de hel. Ik bad omdat ik zoo bang was om verloren te gaan" (Venter 1853:3). 
Wanneer die begeerte tot "wêreldsgesindheid" of gierigheid as jong meisie by haar opkom, doem die besef van sonde en skuld by haar op: "Ik zag en gevoelde inwendig, hoe dat ik voortliep van zonde tot zonde, en met snelle schreden naar de hel voortholde. Het sloeg mij zoo neder dat ik dacht, had ik den Heer maar zoo vlijtig gezocht als dat ik der werelds vergankelijk goed najaagde, wie weet wat de Heere aan mijne ziel zoude gedaan hebben; maar nu zal het te laat zijn" (Venter 1853:4).

Op die wysie van "Gansch treurig en verslagen", stort Hester Venter haar eie onwaardigheid in digvorm uit:

3. Ik durf tot u niet komen,

o Jezus, reinig mij,

Giet uit genade stroomen,

Mijn hart gereinigd zij.

Mijn zonden staan als bergen,

Mijn misdaad is zoo groot,

Heer, wil u mijns ontfermen,

'k Lig voor u naakt en bloot.

(Venter 1853:185-6)

Vanweë die afgesonderde lewenswyse van die trekboere, kom Hester min met mede-gelowiges in aanraking. By geleentheid reis sy na die Kaap, waar sy 'n niggie van haar ontmoet - "een geloovige" (Venter 1853:5). Alhoewel sy daarna dors om aan haar niggie haar sieleworstelinge bekend te maak, weerhou sy haar daarvan om die moontlike negatiewe oordeel oor haar geestestoestand te hoor. Andersyds kon sy egter ook nie swyg nie: "Ik kon echter door den grooten angst dien ik inwendige gevoelde, ook niet geheel zwijgen, maar openbaarde haar toch een weinig van mijnen zwaarmoedigen toestand waarin zij mij een weinig opwekte en moed gaf" (Venter 1853:5). Kom sy by geleentheid in die kerk ervaar sy onder die prediking ' $n$ gevoel dat sy vir die hemel te lig bevind is: "Dood in zonden en misdaden, vervreemd van het leven Gods, geene hope hebbende door de onwetendheid; maar mij, de allerminste, is barmhartigheid geschied" (Venter 1853:7).

\subsection{2 "In de maand December 1796, behaagde het den Heer, mijn blinde hart te openen."}

Sekerheid van geloof word by Hester Venter 'n obsessie wat haar hele godsdienstige lewe oorheers. In haar boek teken sy aan dat sy in die maand Desember 1796 tot bekering gekom het en dat sy, "ellendige, met gevoeligen indruk en levendig inzien, met waar berouw en smeltende droefheid over mijne zonden, overtuigd werd dat er in hemel of aarde geene zaligheid te 


\section{Bevinding en geestelike verlating op die limiete}

zoeken of te vinden was dan in den naam van Jezus Christus ..."13 (Venter 1853:8). Selfs na haar bekering is haar lewe 'n deurlopende hunkering en stryd om sekerheid van geloof; 'n deurlopende stryd om die gevoel van brandende liefde vir Christus te hê. Kort na haar bekering in Desember 1796 raak sy "zwaar beangstigd onder het gezigt van mijne zonden", met "een benaauwd bekommerd gemoed" dat die Here haar nie genadig is nie en dat haar siel vir die hel bestem is. In dié bekommerde staat bly sy die hele maand, tot met die 28ste van dieselfde maand, "toen de Heer zich aan mij ontdekte meet een volle blijdschap" (Venter 1853:8). Die ervaring wat sy gehad het "duurde bijna den halven dag, dat ik in zulk eene geestelijke blijdschap was met mijne ziele" (Venter 1853:8). Die blydskap slaan bykans onmiddelik weer om in droefheid: "O ja, de geestelijke blijdschap was mij zoo zoet; en was zoo bedroefd, dat ik weêr verduisterd werd. Ik zeide, wie weet of ik wel zoo eene zoetigheid van mijn leven weer smaken zal, en ging in die duisternis weer in de wereld" (Venter 1853:8-9). Vir ongeveer 21 dae beleef sy haar geestelike toestand as een wat "met de wereld weggegaan was." Sy raak egter so swaarmoedig vanweë die ervaring dat "er voor mij gansch geen genade was; dat mijne zonden te veel en te groot waren dan dat zij mij vergeven konden worden, en ik werd zoo geweldig bestreden van den boozen vijand, dat er voor mij niet anders dan de hel bereid was" (Venter 1853:9). Spoedig daarna beleef sy weer 'n geestelike terugslag wat vir veertien dae duur: "En deze dikke duisternis zal wel een veertien dagen geduurd heben, dat de dag mij even zwaar was als de nacht en de nacht als de dag, door den last van mijne zonden. Ja, ik vond geene verligting voor mijne ziel. Ja, het was of het heden mijn tijd was van verderving" (Venter 1853:9). Die blye uur breek aan dat sy die ervaring kon hê dat die Here "ontdekte ... zich aan mij, waarop ik met een blijmoedigen staat van al mijne zonden verlost werd" (Venter 1853:10). Die geestelike ervaring wat sy gehad met die wete dat sy van haar sonde verlos is, beskryf sy as 'n intieme ervaring van liefde tot Christus: "Ja, ik vond zoo veel heerlijkheid in den Heer Jezus, dat ik het niet uitschrijven kan noch verhalen. Het was alles begeerlijk wat aan den Heere was. Mijne ziel was vol blijdschap en smolt als het ware weg in liefde. Ach ik kon de Heere Jezus niet weer laten gaan" (Venter 1853:10). By herhaling verval sy weer in geestelike duisternis, net om dan weer die liefde tot Christus te beleef: "Het was mij alzoo ettelijke malen gebeurd dat ik met liefde getrokken werd, dat ik niet wist in welk eene zoete hemelsgestalte ik was. Dan kwam mij te binnen: De droefheid naar God werkt eene onberouwlijke bekeering tot zaligheid. Maar in zulke zoete gestalten kwamen mij weer mijn zonden voor 't gezigt, en schenen zoo groot en zwaar voor den Heer dat ik dacht, nu zal de Heere niet weer naar mij omzien, ja, dat ik mijzelve voor een walglijk zondig monster 
aanmerkte voor den Heer met mijne zware zondeschuld" (Venter 1853:11). Aldus bly haar ervaring 'n voortdurende ronddobber tussen die soetste gemeenskap met Christus; net om dat weer in diepe duisternis van onsekerheid te versink.

\subsection{3 "(A)Is ik zoo met mijne speelmakkers in losbandigheden had mede gedaan ...."}

Die soeke van die opregte vrome na geloofsekerheid gaan gepaard met 'n ernstige introspeksie en stigtelike lewenshouding - nie net om uitdrukking aan die strewe na vroomheid te gee nie, maar ook omdat die liggaamsgestalte van lewenserns as beginpunt vir die ervaring van geestelike vroomheid dien.

Reeds as kind beleef sy dit dat meedoen aan uitbundige kinderspel, skielik onderbreek word "om mij stil en ongemerkt eensklaps van hen aftezonderen met een benaauwd en angstig gemoed, waar ik maar gelegenheid vond, hetzij achter een bosch of andere schuilplaatsen waarvan zij niet wisten, waar ik dan bang neder zat om te bidden, gebeden die mijne moeder mij geleerd had" (Venter 1853:3). Die kindergemoed "maakte ... veel werk om geestelijke liederen van buiten te leeren" (Venter 1853:3). Die gemoedsgestalte van haar kinderjare maak mettertyd plek vir 'n hunkering na die prag en die modes van die tyd (Venter 1853:3-4). Die ervaring van sondeskuld dompel haar in "zware zielsangst en het was mij als of ik op den rand van de hel stond ..." (Venter 1853:4). Die uiterlike manifestasie van haar skuldbewussyn word selfs deur haar eggenoot opgemerk (Venter 1853:5). Meerendeels beleef sy haar sielsbenoudheid as 'n swaarmoedige toestand waarin sy die knaende vrees oor haar eie verlorenheid beleef (Venter 1853:6).

Die bepeinsing oor haar eie geloofstand, bring Hester soms daartoe om die eensaamheid op te soek. By geleentheid toe sy 'n "dikke duisternis" vir veertien dae lank ervaar, sodat "de dag mij even zwaar was als de nacht en de nacht als de dag, door de last van mijne zonden", sit sy by die watervoor met haar siel "vol zondenangst"; "ontdekte de Heer zich aan mij, waarop ik met een blijmoedigen staat van al mijne zonden verlost werd" (Venter 1853:910). Bepeinsing bring haar tot diepe selfondersoek: "O ziel, neem eene proeve in zelfonderzoek, ja vraag uwe ziel zelve af, wat wilt gij kiezen" (Venter 1853:82)? Wanneer sy alleen is, ervaar sy ook die aanslae van die Satan en is haar ge Venter waarwordinge van die geestesstryd waarin sy dikwels verkeer sterker (Venter 1853:13).

Asketiese geneigdheid van die soekende siel na die sekerheid van geloof en die bevindelike gerigtheid op Christus in die gereformeerde piëtisme 


\title{
Bevinding en geestelike verlating op die limiete
}

loop paralel met die bruidsmistiek. By Hester Venter is dit nie anders gesteld nie. Die besef dat die mens nie sy hoogste doel op aarde vind nie, bring haar tot 'n emosionele belydenis van eenwording met Christus:"Hemelsche liefde, Gods liefde, overstelpte liefde, zielsverrukkende liefde, ik verdwijn voor $u$, o hooge God, in nietigheid; mijn lieve Jezus, mijn menschwordende Jezus, mijn verheven Koning, mijn gekruiste Heiland!" en "mijn eeuwig huis, mijn lieve Jezus, mijn Koning, mijn God!" (Venter 1853:35). In die trant van die bruidsmistiek besing sy haar liefde vir Christus:

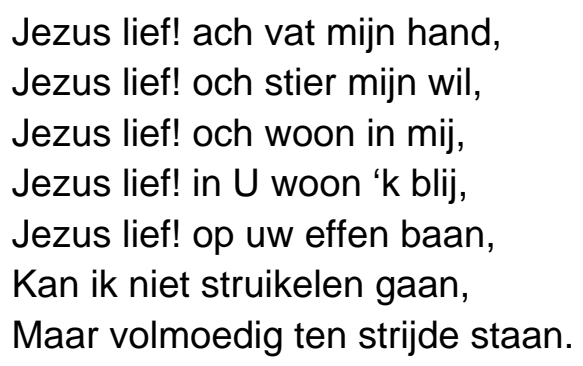

(Venter 1853:52)

Christus word besing as die

\begin{abstract}
Hoogwaardige, zuiver, reine, Vredevorst, Zone Gods, heil fontein, lichte zon, heldere bron, Heer der Heeren, groote Heiland, Koning der eere, medeleidende hoogepriester, lieve Heiland die uwe kinderen door uw woord en geest regeert, mijn groote voorspraak en Middelaar die uit den dooden is opgewekt ten hemel, ... verhoogde Heiland en Middelaar, vol majesteit en groote kracht in heerlijkheid, die altijd leeft om voor mij te bidden, dien de vader altijd hoort, gij hebt mij het harte genomen, o mijne zuster, mijne bruid, o fontein der hoven, sprinkader der wellusten, ... Heere, die uw aangezigt zoeken, die $u$ beminnen, Heere, die u vreezen, die hunne zielen in lijdzaamheid en ootmoedige nederigheid voor $u$ nederstorten, lief dragende God, medelijdende hoogepriester, o mijn Koning en mijn God!"
\end{abstract}

(Venter 1853:68-9)

Elders roep sy uit: "Dierbare Jezus, groote verlosser, lieve Heiland en Zaligmaker der wereld, menschlievende God, mijn lieve Jezus, groote herder der schapen ..." (Venter 1853:107) en "Heilige Jezus, verhoogde Middelaar, hoogwaardige God, Zions Koning, majesteit, vol genade, liefde trouw ..." (Venter 1853:109). Sy kan Christus se "zoete aangezigt niet missen, en buiten zijne liefde gemeenschap niet leven; hij is de ware vrede, de zoete rust, dewelke die ziel door genade boven het stof doet leven, met geringe, lage 
gedachten van zichselve, daar het leven in Christus in het goede verborgen is" (Venter 1853:72). Christus se versoenende dood aan die kruis word besing in terme van:

Heilige Jezus, gehoorzaam God, Lieve Jezus, zondaars God en menschen lot, Regtvaardig Zoon van God, Heer der heerlijkheid, Gij ware levens brood, die zoo gewillig lijdt, O ware levens bron tot zondaars zaligheid, O Hemels liefde-min, o goddelijk genâ, Dat 't menschelijk verstand geheel te boven ga ...

(Venter 1853:85)

In 'n gedig "Aangenomen ziel, gedenk aan de dagen van ouds", word van die geestelike eenwording met Chritus gesing:

Geheel verwonderd, teer,

Vol liefde en blijdschap, Heer!

Het is alles lief en wonderbaar,

Zij leeft voor zich niet meer. - Maar

Christus leeft in haar,

Heil'ge, zaal'ge, hemelrust,

Door Jezus mond gekust ...

(Venter 1853:102).

Elders sing sy van die liefde vir Christus:

In Jezus armen met liefde viel, o Wonder, ziels verrukte stonden, Tot genade mijner zonden, In plaats van eeuwig dood en wee ... Vlammend liefde, heilig dronken, In de liefde ingeschonken, Hoorn des altaars, hemel min, Daar zijn Geest my overheert, Ik verlies mij zelf daarin, In Jezus kruis gerantsoeneerd

(Venter 1853:145)

en weer

Een dorstig hart dat hijgend brandt,

Een zoete brand, naar het dierbaar pand, 


\section{Bevinding en geestelike verlating op die limiete}

Mijn ziel bezwijkt door liefde teêr,

Waar is mijn Heiland en mijn Heer?

(Venter 1853:165)

Later skryf sy:

o Mijn schoonste, mijn beminde,

o Mijn zoete wellekom;

o Mijn liefste ziels vrindinne!

Allerliefste Bruidegom.

o Mijn troost, mijn licht, mijn leven,

o Mijn een'ge toeverlaat,

Aan wie ik mij heb gegeven,

Gij zijt die mijn ziel verzaadt.

(Venter 1853:166)

\subsection{5 "Zij waren van Smijtegeld, handelende over de gekrookte riet"}

Die gereformeerde piëtisme van die 17 de en 18de eeue, is sterk vanuit die vroomheidsliteratuur van die tyd gevoed. Karel Schoeman (1997:256, 258, 259) wys daarop dat die wedersydse invloed van die gereformeerde en Lutherse piëtisme aan die Kaap tot ' $n$ besondere tipe vroomheid aanleiding gegee het. Dit is versterk deur die vroomheidsliteratuur wat vanuit beide strominge aan die Kaap gesirkuleer het. $\mathrm{Na}$ ' $\mathrm{n}$ ernstige sieleworsteling tydens 'n besoek aan Kaapstad, "en ... op den weg weer in zoo zwaren zielstoestand geraakte", openbaar sy selfs aan haar gelowige niggie iets van die sieleworsteling wat sy deurmaak. Die swaarmoedigheid bly haar egter by en koop sy van die piëtistiese skrywer Smijtegeld sy bekende werk Het Gekrookte Riet. ${ }^{14}$ Op die terugreis uit die Kaap lees sy in die werk:

De eerste dag dat ik uit de Kaap was sloeg ik het eene boek open en las juist op die plaats dat hij schreef even als ik mij in mijnen toestand bevond, en waarin ik zoo jammerlijk gekweld werd; en van toen af scheen het alsof de vijand gansch geen magt meer had om mij daarmede te betwisten en mij verder in mijn zielstoestand en duisternis te houden. Ik had lust om in die boeken te lezen, hoewel ik ze niet door bevinding begrijpen kon

(Venter 1853:6)

Skynbaar was dit Hester Venter se eerste kennismaking met boeke van 'n piëtistiese inslag. By 'n latere geleentheid, toe sy "vol liefde in den Here, met 
volle vreugde en blijdschap in mijne ziel" die Here loof en haar siel rus vind in die gemeenskap met Christus, haal sy aan uit Lodensteyn (1620-77):

Hoog omhoog mijn ziel naar boven,

Hier beneden is het niet,

Het regte, leven, lieven, loven;

Is maar daar men Jezus ziet" ( Venter 1853:23). ${ }^{15}$

Wanneer sy die Here loof verwys sy later ook na Sluijter (c1700-76):

In een toegesloten kamer,

Of in eenzaam vrije veld,

Raakt en blaakt hij aangenamer,

Met zijn liefde zoet geweld

Dan daar edele wereld woelt,

Die Gods Geest niet kent noch voelt;

Des hoogen Konings vreugde maal,

Hier boven in 's hemels opperzaal,

Daar het maar hier de voorproef zijt,

Dat ons den hemel weg in leidt,

Hier zijn wij in het aarden vat,

Hier boven is de vreugde schat,

Daar alles is volop gedischt,

Van liefde vreugd verzadenis.

Die indruk bestaan dat haar kennismaking met Smijtegelt haar tot 'n liefde en waardering vir die vroomheidsliteratuur van die Nadere Reformasie gelei het. Die beskrywinge van haar gemoedsingesteldheid vertoon ook heelwat paralelle met tipiese formuleringswyses van die outeurs van die Nadere Reformasie. $^{16}$

\subsection{6 "(W)aardoor de Satan mij bestreed dat ik te veel gezondigd had ..."}

Hester Venter se Bekeeringsweg is 'n beskrywing van die worsteling om die bevindelike versekering van Jesus se liefde en 'n stryd teen twyfelmoedigheid, volgens haar deur die Satan ingeprent. Haar worsteling beskryf sy soos volg: "Ik bleef zoo gedurig aan den Heere denken. Hij was mijn raad; in Hem moest ik het alles vinden. Ja, ik zag ok dat ik alle geboden Gods overtreden had; waardoor de Satan mij bestreed dat ik te veel gezondigd had, in de hoop dat ik tot razernij vervallen zou; maar ik bleef gedurig aan den Heere Jezus denken ..." (Venter 1853:9). Sy beskryf haar gewaarwordinge van swaarmoedigheid as "lasterlijke bestrijding van den Satan" (Venter 1853:10); 'n gevoel van rampsaligheid "in mijne zonden-schuld" (Venter 1853:11); na 'n 


\section{Bevinding en geestelike verlating op die limiete}

gevoel van "bezwijking" verkeer sy weer "in eenen zwaren strijd met den Satan" (Venter 1853:12); daarna "viel de Satan" haar "met storm aan" (Venter 1853:13); in haar siel ervaar sy asof sy met geweld uit "Satans klaauwen gerukt werd" (Venter 1853:13); na drie weke van sielsgeluk in die nabyheid van Jesus, raak sy weer "in eene zware bestrijding .... (m)et den Satan, die mij gedurig betwistte dat in al mijn werk geene waarheid was" - soveel so dat sy selfs na liggaam en siel siek word (Venter 1853:14); wanneer sy die ervaring van sielsverlating het, skryf sy van haar "zielsgesteldheid toen ik des avonds ging liggen, dat de Satan zich inwendig aan mijne ziel vertoonde, doch in de gedaante en met de werkzaamheid van een' engel des lichts" (Venter 1853:14); soms ervaar sy die aanvalle van die "vyand" in die aand:"Het gebeurde den avond hierop dat de vijand mij met storm aanviel, dat de plaats daarop zag dat ik geen geloof had, dat ik de hemelsche vreugde niet weer zou genieten, dat ik dan een bitter leven op de aarde zou hebben"; sy bid tot die Here, "verbreek de banden van den Satan, dat mijne ziel niet bezwijke onder zijne magt ..." (Venter 1853:21-22); die gevare wat haar bedreig neem ook die vorm aan van "vele ... beproevingen; eene aanlokkende wereld met schepsels liefde, o mijne ziel daar gij tegen waken moet; o wat valt het bitter te worstelen onder de verberging van Gods heiligen aanschijn" (Venter 1853:49); selfs tydens die gebruik van die Nagmaal, "was ik onder het prediken zoo verduisterd, ik had met groote verdorvenheid te strijden, met zondige ijdelheden gekweld, dat ik in droefheid volkomen ter nedergeslagen was ..." (Venter 1853:55).

Die aanslae van die Satan is vir Hester Venter 'n werklikheid wat selfs fisiese ongemak tot gevolg het; dit is die bevindelike werklikheid van die afwesigheid van God - die teenpool van die nabyheid van Christus tot versterking en verkwikking van haar droewige gemoedstoestand. Dit is ook die ervaring van geestelike verlating en die afwesigheid van God in haar lewe. Die tema van geestelike verlating kom derhalwe in die Bekeeringsweg konsekwent na vore. Dit is opvallend dat van die sterkste ervaringe van geestelike verlating wat Hester in haar Bekeeringsweg beskryf, plaasvind nadat sy 'n hoogtepunt in haar geestelike bevindinge gehad het - selfs nadat sy Christus se liefde dermate ervaar dat sy "niet wist in welk een zoete hemelsgestalte" sy was, kom die twyfel weer na vore: "Dan kwam mij te binnen: De droefheid naar God werkt eene onberouwelijke bekeering tot zaligheid. Maar in zulke zoete gestalten kwamen mij weer mijn zonden voor 't gezigt, en schenen zoo groot en zwaar voor den Heer dat ik dacht, nu zal de Heere niet weer naar mij omzien, ja, dat ik mijzelve voor een walglijk zondig monster aanmerkte voor den Heer met mijne zware zondeschuld" (Venter 1853:11). By geleentheid duur die angs vanweë haar sonde-ervaring vier dae 
lank en beleef sy dit "als of ik de sprankels van de hel voelde" (Venter 1853:11-2). Op die vierde dag voel dit vir haar asof sy "aan het zinken was naar de hel; ik dacht ik lag onder Gods vloek en toorn" (Venter 1853:12). Haar sondebewussyn is so erg dat sy "in bezwijking" roep dat sy die stryd gewonne gee; daardie aand ervaar sy haar toestand as hopeloos - "voor den Heere als dood in zonden en misdaden, en tot de helle gedoemd ..." (Venter 1853:12). Nadat sy hierdie geestelike terugslag oorkom het, word sy dermate aangegryp dat sy 'n geestelike stilstand ervaar en dat sy tot vier keer in "verrukking" kom en die geestelike blydskap van Christus se nabyheid ervaar (Venter 1853:13). Kort daarna ervaar sy weer "ene diepe verlating" van "zielsgesteldheid" vanweë die Satan se voorstelling van homself as 'n engel van die lig (Venter 1853:14). Die toestande van geestelike verlating wat sy ervaar word beskryf as aanvalle van alle kante (Venter 1853:15); 'n worsteling "bijna den geheelen nacht tegen de wereld en mijn verdorven vleesch en bloed" (Venter 1853:15) tot die mate dat sy ervaar dat haar bloed nie meer vloei nie (Venter 1853:15).

\subsection{7 "(W)anneer de Zoon des menschen zal komen op de wolken des hemels, dat heerlijk zal zijn"}

Waar die eerste gedeelte van Hester Venter se Bekeeringsweg veral op die daaglikse worstelinge teen die aanslae van die Satan fokus, bevat die tweede helfte van die werk sporadiese verwysings na haar uitsig op die dood en die wederkoms. Van die koms van Christus skryf sy in persoonlike terme:

... mijn Jehova, wiens laatste komst heerlijk zal zijn, wanneer de Zoon des menschen zal komen op de wolken des hemels, dat heerlijk zal zijn, wanneer hij als regter verschijnen zal om het aardrijk regtvaardiglijk te rigten; ook zal het heerlik zijn, wanneer hem millioenen engelen zullen verheerlijken met onnoemlijke vreugde, heerlijk dienen, heerlijke blijdschap, vol 's hemels lof, eeuwige vreugde zonder storing ...

(Venter 1853:70)

Sy vertrou dat God haar deur sy Gees verseël en oorbring in die nuwe Jerusalem (Venter 1853:71). Op die wysie van "o Heere, Davids Zoon" verklaar sy haar geloofsvertroue in die almag van God:

2. Gij zijt een vaste muur, Wie kan mij hier verkeeren, Al valt de storm zuur, Mijn hoop blijft op den Heere, Ja Christus is mijn Heer, 


\section{Bevinding en geestelike verlating op die limiete}

Die over dood en hel, Ten hemel triomfeert, En al ter nedervelt

(Venter 1853:149)

Die lewe op die limiete was hard en eis dikwels die lewens van bekendes binne die familiekring, By geleentheid van die sterwe van Susanna Lasija Kruger, 'n dogter van Hester se oom Stephanus, die broer van Johanna Maria Buys (gedoop 22 Oktober 1752), getroud met G Kruger, skryf sy 'n gedig van nie minder as 31 verse oor "Op het zalig overlijden van Susanna Lasija Kruger, geboren Buis" (Venter 1853:154-7). Die inslag daarvan is die ewige rus wat die afgestorwene ingaan; die vreugdevolle ontmoeting met die Lam en die juigende einde van die lewe in die hiernamaals, teenoor die stryd wat die agterblywendes op aarde moet voer:

6. Glans, hemelsch heerlijke kust, Heilbeek der wellust, Loof roemende Gods lof, Vreugde hemelsch bruiloft, Bij Jezus in volle rust.

13. Des Konings vreugd onthaal

En flonkerend heil gepraal, De straten zijn van goud En op het heil gebouwd Heil glinsterend lichte straal.

30. Hier proeven wij ten deel, Zij in volmaakt geheel, In Jezus min, In volle zin, Wat heerlijk kroon gewin

(Venter 1853:154-7)

By die dood van Anna Martha Aucamp (gebore Van der Walt) ${ }^{17}$ skryf Hester Venter 'n gedig oor die dood van die jonge meisie wat in die fleur van haar lewe oorlede is. Die sentrale gedagte van die gedig is die ewige rus en vreugde wat die oorledene by Jesus smaak; haar redding wat deur die bloed van Christus verseker is en haar eenwording met die "bruid van God" (Venter 1853:158-9): 
1. Anna is van hier gevaren,

In het bloeijen van haar jeugd;

Zalig bij de hemelscharen,

Zwemmend in de hemelvreugd.

Bij de zielen der volmaakten,

Vrij gekocht door Jezus bloed,

Daar zij in de liefde blaakten,

Aan het kruis haar zond' geboet.

8. Anna is nu heen gevaren,

Verre boven ons bereik,

Met Gods bruid haar stem te paren,

Jezus lof en heerlijkheid.

Eeuwig met de hemellingen,

God te loven, prijzen, zingen,

Hallelujah, loof den Heer,

God en Lam, ei, geeft hem eer!

Die werklikheid van die sterwe van geliefdes dring haar tot die vermaning van die sorgeloses dat hulle geestelik moet ontwaak:

Weinige omstanders die met een diepen indruk in het harte zijn, wanneer zij een lijk ter aarde bestellen, niet denkende nu deze, morgen kan het mij ook gebeuren, o dat zij in ware boetvaardigheid voor den Heere mogten invallen en schreijen tot God om den geest der genade, en der gebeden om met verslagenheid tot den Heere te vlugten eer het te laat mogte zijn, en de eeuwigheid hen verrast; ach dat de zorgeloozen mogten ontwaken, die nog aan geen verandering des harten denken ...

(Venter 1853:59)

\section{BEVINDING EN VERLATING OP DIE LIMIETE:DIE LOKALISERING VAN HESTER VENTER SE VROOMHEIDSMISTIEK BINNE DIE HISTORIESE KONTEKS VAN DIE TYD}

In sy werk oor die mistieke weg by San Juan de la Cruz, het Troelstra $(1976: 1,71)$ opgemerk dat veral tye van groot sosiale en ekonomiese onsekerheid besonder geskik is vir 'n opbloei van die mistiek. In sulke omstandighede kry die gewaarwording van angs makliker vat op die menslike gees en dryf dit mense tot 'n soeke na sekerheid - soms soek en vind hulle dit 


\title{
Bevinding en geestelike verlating op die limiete
}

buite hulleself in die godsdiens; dikwels bied dit nie voldoende vastheid nie en keer mense in hulleself om die sin van hulle bestaan te oordink. In individuele bepeinsing ontdek die soekende siel soms die innige gemeenskap met God as die enigste bron van sekerheid teenoor alle wisselvallighede van sy of haar aardse bestaan (Troelstra 1976:1). ${ }^{18}$ Van die opbloei van die mistiek in tye van politieke en ekonomiese onsekerheid verklaar Troelstra dat die onsekerheid gedurende die tweede wêreldoorlog, innerlike spanning as gevolg van die snel mekaar opvolgende lewenspatrone voortspruitend uit ekonomiese ontwikkelinge en 'n onvoldoende meegroeiing van die kerke 'n sterk mistieke wending tot gevolg gehad het - tewens dien die mistiek as 'n kompensasie vir die intellektualisme, materialisme en die tegnokrasie van die vorige eeu (Troelstra 1976:1).

Selfs 'n oppervlakkige beoordeling van die mistieke grondslag van Hester Venter se Bekeeringsweg bevestig dat die omstandighede waaronder sy in die tweede helfte van die 18de eeu verkeer het, tot 'n groot mate die voedingsbodem van haar mistiek-getinte teologiese lewe was. Die fisiese bedreiging in die vorm van die Boesman en Xhosa-aanvalle op die oostelike grens, die afgesonderde bestaan en die stryd om ekonomiese oorlewing het veel daartoe bygedra dat introspeksie, die soeke na innige gemeenskap met God en mistieke oordenking deel van haar alledaagse bestaan was. Dit is sterk vanuit die teologiese literatuur van die tyd gevoed. In J van Lodensteyn se Uytspanningen, waaruit sy in haar Bekeeringsweg aanhaal, neem die mistieke bepeinsinge oor Christus 'n sentrale plek in. In 'n lied oor Hooglied 5:2 beskryf Lodensteyn (1721:14-5) die innige verhouding tussen Christus en die gelowige wat in 'n toestand van slaap verkeer:

\author{
Ick was wat aan het sluymeren \\ O! diere slaap-sugt! \\ O! diere slaap-sugt! \\ O! diere / diere slaap-sugt! \\ Hy klopt' / en riep nog: \\ Ick hoord' / en sliep nog: \\ Sijn woorden schenen \\ Door dampen henen / \\ Door damp van lusten \\ En sorg loos rusten. \\ Hy trock sijn hand te rug / \\ Hy trok sijn hand te rug / \\ Hy trock sijn hand te rug / \\ O! dierbre slaap-sugt!
}


In 'n gedig "Den Naakten Jesus, of Aandagt op Johannes 19:23"19 beskryf Lodensteyn (1721:37) die mistieke band tussen die gelowige en die gekruisigde Christus:

Vermogend Goud, dat om uw glans gepresen / Uw Dienaars kluysterd / en had my wel eer Gevangen / my sal na dees tijd veel meer Den naakten Jezus wesen.

$\mathrm{Na}$ dit ick dien had in mijn oog gekregen / Strax was den Amethijst beswalcht en 't sonck Al wat te vooren preuts en pragtig blonck. Door 's naackten Jesus segen. 'k Laat hem / dien 't lust / na groote schatten delven / 'k En wensch geen Scepter nog geen groot gebaar Dan Magt / geen pragtig kleed van Jesus; maar Den naackten Jesum selven.

Dat mogt gy / Babel / dus uw heyl vermindren / En kiest / en kust / een doeck / een lomp / een staff / Die Jesus aan die schelmen schonck:en gaff Sig selven naackt sijn kinderen." In die gedig "Jesus met sijn Bruyd in Twee-spraak" word die dialoog tussen Christus en die gelowige beskryf (1721:103):

"I. Bruydt. Myn Jesu lief / mijn aldertrousten borg!

Wat is dat dus mijn hert van d'ydle sorg

Geslingert dubt / wat nog het eynd met my.

"II. J. Loop slegs / mijn kind mijn lief/ mijn lam / mijn lust Ick sta voor 't eynd. Br. Mijn Roem / mijn Rots / mijn Rust / Mijn Hert / mijn Hooft / mijn Hulp / mijn Heyl / mijn Hoop /."

In Willem Sluiter ([1776] 1838:28, Jeremia's Klaeg-Liederen) se "'t Hemelsch Halleluja over de Bruylof des Lams" ${ }^{20}$ is die mistieke ondertone onmiskenbaar:

Want siet, de Bruylof is gekomen Des Lams; en sijn verkoren Bruyd. Sijn wijf / heeft cierlyk tot de soomen, Haer selv' bereyd. Haer rouw is uyt.

Elders, in sy "Gezangen" (Sluiter [1776] 1838:75) sing hy: "O Jesu! 's levens bron/laat my soo zijn geschonken Uit d' over soete beek van uw wellustigheyd /Dat ik mijn geest gevoel as van uw liefde dronken." 


\section{Bevinding en geestelike verlating op die limiete}

In Bernardus Smytegeld (1860:II, 79) se Gekrookte Riet, by die behandeling van die kenmerke waaraan die gelowiges kan weet dat "Jezus onze Liefste is", word, met verwysing na Mattheus 12:20, 21 en Hooglied 2:16; 7:10 en 8:10, opgemerk:"Wat moet dat aangenaam wezen / als eene ziele zoo liefelijk omhelsd wordt met kussen van Gods mond! Ach! Mogt een dat hebben/zegt een kind van God!"21

Die bronne wat sy ter hand gehad het, staan in die tradisie van die gereformeerde mistiek. Die mistieke hunkering in haar gees, bied die vertrekpunt vir Hester Venter se smag na die bevindelike ervaring van die versekering van die redding.

Deur die oplewing in die gereformeerde mistiek kom die klem op die bevindelike piëtisme ook sterker op die voorgrond. Die bevindelike mistiek kom in twee gestaltes na vore:dit behels sowel die unio mystica (die mistieke vereniging met God), as die via mystica (die weg tot die vereniging met God) (Brienen, 1978:14). In die Bekeeringsweg kom veral die einddoel van die mistiek, naamlik die ervaring van die eenheid, van verbondenheid met God sterk na vore. ${ }^{22}$ Haar hunkering is eerstens na die Godservaring as sodanig, waaraan die weg om dit te bereik ondergeskik is. Die aard van die bevindelike mistiek wat in Hester Venter se Bekeeringsweg na vore kom, kan beskryf word as die begeertes en handelswyses in die beoefening van haar geloof, gerig op die praktyk van die godsaligheid, lewensheiliging en persoonlike verkeer met God ten einde die vreugde van geestelike eenwording met Christus te geniet.

Die mistieke huwelik tussen Christus en die gelowige in Hester Venter se teologiese belewenis is nooit afgehandel en afgerond nie; so ook die bevinding - die nadering tusen God en mens word deur verwydering opgevolg; op die verrukking volg die donker nag van geestelike verlating; sy leer haarself intens ken in haar diepe en totale verlorenheid, maar verloor haar ook in die oorgawe aan Gods barmhartigheid. Wanneer, soos Smytegeld (1860:202) dit noem, die "stondetjie der minne" aanbreek, kan sy slegs vol ontroering en verwondering die genot van die geestelike gemeensaamheid met Christus smaak - ervaar sy dat sy uit haar diepe verlorenheid gered is en dat sy verheerlik voor die aangesig van God staan vanweë die onbeperkte goedheid van God. Die toestand van geestelike verlating is 'n werklikheid wat in die lewe van die gelowige selfs jare van doodsheid en dorheid mag oplewer. Dié "stondetjies" is dikwels van korte duur, maar van onbeskryflike waarde vir die siel deur ongeloof geknel. Smijtegeld (1860:202) skets dit 
treffend:"daar komt het stondetje der minne; hij grijpt ze in het harte / hij verlost ze uit het geweld des duivels, Hebr. 2:14, en van onder de heerschappije des Satans. Daar kan ze die sterk gewapende niet meer in zijne magt houden. Hij haalt ze uit het rijke des Duivels."

Méér dikwels worstel Hester met die gevoel van geestelike verlating dit is 'n werklikheid waarmee sy deurlopend in haar gemoed stry. Enersyds is daar by haar die ekstase en vreugde van geloofsekerheid, dan weer die donkere nag van geestelike verlating; aan die een kant bevind sy haar in die totale verlorenheid en andersyds verloor sy haarself weer in die oorgawe van die liefde aan Gods barmhartigheid; wanneer die uur "der minne" slaan kyk sy vol bewondering en ontroering terugskouend na haar worstelinge om geloofsekerheid en stryd om eenwording met Christus. Uit die Bekeeringsweg blyk dat die praktyk van die beoefening van die godsaligheid dikwels ook die Christelike stryd oplewer.

Gisbertus Voetius, een van die grondleggers van die gereformeerde piëtisme, beskryf die werklikheid van die geestelike verlatinge in die lewe van die Christen-gelowige met verwysing na die Christelike lewensstryd as "alle moeilijkheden in dit leven, zoo schandelijke als bedroevende" (Voetius [1646] 1898:11). Die "droewige" lewensprobleme wat tot geestelike verlating lei, kan geestelik of liggaamlik wees: "De uiterlijke verdrietelijkheden en aanvechtingen", kan op hul beurt siekte, armoede, vervolging, ensomeer wees (Voetius 1898:11). Daarbenewens onderskei Voetius tentatie, synde "strijd tusschen vleesch en geest; eene kranke en ontroerde conscientie; verlating of worsteling der conscientie; strijd en verzoeking des satans; gevoellooze godsdienstpleging; droefheid des gemoeds of des geestes; het gevoel van den toorn Gods en de worsteling daarmede; desolatie of mistroostigheid; geestelijk gemis of dorheid (Voetius 1898:12), van geestelijke verlating, synde "een innerlijk kruis of geestelijke smart en aanvechting, waardoor een mensch, nu waarlijk tot God bekeerd zijnde, niet gevoelt de verheuging zijns harten in God en goddelijke dingen (Voetius 1898:18). Die geestelike verlating, as gemis en gebrek aan "goede gesteldheid en gestalte", is slegs vir 'n tyd, naamlik die tydelike afwesigheid van die vreugde en gerustheid van die vrug van die geloof. Die "naaste" doel waartoe God die verlating stuur, is dat dit gelowiges beproef en aan hulleself en andere beter bekend word; sodat in hulle die begeerte na die genade en die heerlikheid steeds meer versterk mag word, ten einde die verborge sondes te ontdek (Voetius 1898:37). ${ }^{23}$

In sy werk Geestelijke Verlatingen wys Johannes Hoornbeeck ([1646] 1898) daarop dat geestelike verlating deur vroeëre skrywers onder die tema van versoekinge, binne die konteks van Hooglied, behandel is. Volgens 


\section{Bevinding en geestelike verlating op die limiete}

Hoornbeeck kan die geestelike verlatinge en die omstandighede daaraan verbonde slegs reg begryp word deur hulle wat die Gees van God ken. "Geestelike verlatinge" is die swaarste aanvegtinge wat die siel kan hê. Dit kom die sterkste ooreen met die helse angste en smarte, wanneer dit God behaag om sy kinders op die rand van die hel na die hemel te voer (Hoornbeeck 1898:68); dit is "eene zwarigheid des geestes, in de ziel, over geestelijke zaken" (Hoornbeeck 1898:68). Synde "ontberinge" kan dit slegs verstaan word deur die teenoorgestelde - naamlik genade - te begryp (Hoornbeeck 1898:68-9). In die toestand van geestelike verlating verkeer die siel in 'n toestand van "erbarmelijke droefheid en dorheid; in plaats van rust ondervindt ze niets dan onrust en mistroostigheid, ja, dan heeft ze strijd, strijd zelfs met God, die, hoewel Hij haar anders vertroost, nu weigert Zij genadig aangezicht over haar te doen lichten en in toorn tegen haar ontstoken is" (Hoornbeeck 1898:72-3). Die verlossing uit die staat van verlating kom, volgens Hoornbeeck, dikwels wanneer dit met die siel die swaarste gesteld is en die verlating op die hoogste loop (Hoornbeeck 1898:281). Die resultaat van die uitkoms is dan verligting van die kwaad, wegneming daarvan, vrede en geestelike vreugde (Hoornbeeck 1898:273-294).

Die kernelemente van die geestelike verlating by Hester Venter vertoon dieselfde aard as die aspekte deur sowel Voetius as Hoornbeeck genoem:Die fisiese omstandighede waaronder sy op die limiete geleef het, die min geleenthede om die kerk te besoek en die klem op die bevindelike eenwording met Christus het 'n groot bydrae daartoe gelewer om geesteservaringe van verlating by haar op te wek; sy ervaar die twyfel aan verlossing as ' $n$ verlating deur die Here, ${ }^{24}$ die ervaring van verlating word deur haar vertolk as ' $n$ afwending van die Here se genade, welke verlating herstel word deur die aangryp van God se genade in en die mistieke eenwording met Christus.

\section{5. "EEN LEGITIEM GEESTELIJK EN THEOLOGISCH EXPERIMENT?"}

Volgens A A van Ruler (II:1971:44) sal alles in kerk en teologie 'n bevindelike "gloed en glans" moet vertoon. Daarmee bedoel hy dat die konfessionele, apostoliese, sakramenteel-liturgiese en polities-kulturele gesigspunte, waaronder die kerk teenswoordig bestaan en funksioneer, nie suiwer gehou sal kan word tensy dit ook met bevinding - dit is die "bevindelike ontmoeting" van die mens met God - rekening hou nie. Sonder bevinding lei leertug tot versplintering; die sending word propaganda, die nagmaal vervaag tot "misterie" en kerstening verval tot aktivisme (Van Ruler 1971:44). Van Ruler is 
gevolglik ' $n$ voorstander van die dringende organiese "opname" van die bevinding in die geheel van apostolaat en belydenis.

T Brienen (1978:160) beaam Van Ruler se opmerking dat alles in kerk en teologie met die bevinding moet rekening hou. Hy plaas egter veral klem op die feit dat in die Reformatoriese teologiese besinning mens aan die pneumatologie reg sal moet laat geskied - méér as wat tot dusver die geval was. Volgens Brienen hou dit onder andere in dat alle teologiese besinning uit welke terrein van die teologiese ensiklopedie ook "in levendig rapport zal moeten blijven met het geloof, dat door de liefde werkt, en zo de uitbouw en opbloei van dit geloof moet dienen" (Brienen 1978:160). Aldus, volgens Brienen, sal die teologie nie in wettisisme, mistisisme, skematisme en kerkisme verstar nie - teoloë sal in hulle besinning op die uitleg van die Woord van God, op die werking en bediening van die Woord, steeds die belewing van die geloof - dus bevinding - dien vanuit die betroubare en magtige beloftes van die evangelie en binne die gemeenskap van die heiliges in al hulle onderlinge dienste, omvat deur die werksame en vrugbare gemeenskap met God: "In zoverre is al de theologie bijbels gelaaden, reformatorisch geaard en evenzeer bevindelijk doorgloeid" (Brienen 1978:160)!

Bevinding is ' $n$ veelomvattende werklikheid. In die bevindelike se lewe staan die opstanding en die gemeenskap aan Christus se lyding sentraal; bevinding is 'n aanneming van Jesus Christus tot behoud en vertroue op Hom; dit ken die versekering van die heil in Christus en is vol toekomsverwagting; dit lê in die gemeenskapsboefening met Christus; dit is 'n oorgawe aan God se leiding; dit leer die lewe van bekering ken; dit is 'n pneumatologiese grootheid en wortel in die vernuwing deur die Gees; dit is ' $n$ ken van God in God se Woord en werk; dit is 'n ontdekking en aanvaarding van die sonde; dit het sowel 'n dimensie na "binne" ('n op-die-hart-gerigte ervaring) as 'n dimensie na "buite" (die gerigtheid op die goeie werke). As sodanig neem dit ' $n$ betekenisvolle posisie in die Reformatoriese teologie in.

Die Bekeeringsweg noodsaak egter ook 'n kritiese oordeel oor die gevare van die piëtistiese geloofsbeoefening van Hester Venter. In haar teologiebeoefening neig die geheel van die belydenis om op die agtergrond te raak en neig die belydenis om Christologiese en pneumatologiese oorwigte te vertoon; haar mistieke ervarings neig daartoe dat die bevinding nie net 'n moment (modus) op die heilsweg van die gelowige is nie, maar in bepaalde opsigte geredelik as voorwaarde van die heil opgeneem kan word. Alhoewel voldoende getuienis oor haar ingesteldheid jeens haar eggenoot en haar verantwoordelikhede in die huishouding ontbreek, skyn haar waardering vir die daaglikse lewe in die Bekeeringsweg 'n verskraling te beleef en die 


\section{Bevinding en geestelike verlating op die limiete}

beleweniselemente op die voorgrond te tree, met die gevaar dat die mistiek as sodanig as 'n sielegrond geneem kan word, eerder as wat God in die geskiedenis téénoor haar staan.

Op sosiaal-teologiese en histories-teologiese gronde is die Bekeeringsweg van besondere betekenis vir sover dit lig werp op die "Doppertrekboere" - 'n eie menstipe by wie puriteinse erns en soberheid en innerlike vermaak in die Here, sy heil, reg, goedheid 'n "teologiese burgerlikheid" tot gevolg gehad het in die vorm van 'n lewe in ekonomiese (en dikwels ook geestelike) armoede waarin hulle op sigself vreugde gevind het. Die diepgrypende nasionale betekenis van die opkoms en bloei van die gereformeerde piëtisme in 'n kernfase van die Afrikanergrensboere se trek na die binneland ${ }^{25}$ en dit wat hulle met geloofsmoed en gelowige hartsoortuiging tot stand gebring het, het tot vandag effek. Die aandurf van die binneland van Afrika in die tweede helfte van die 18de eeu is waarskynlik die sterkste bewys van dit waartoe die oortuigde gemoed van gelowige gereformeerdes, wat daagliks uit die liefde van Christus leef, in staat is.

Met die eerste oogopslag het Hester Venter se Bekeeringsweg min oor die geskiedenis van die Reformatoriese teologie en vir die hedendaagse teologiese gesprek te sê. 'n Dieper analise van haar teologiese diskoers ontwaar egter heelwat momente wat van belang is. Ten spyte van die piëtistiese eksesse wat haar verhaal vertoon, bied dit 'n insig in die godsdienstige worstelinge van 'n persoon wat diep in die hart gegryp word oor eie sonde en onvermoë - 'n insig wat juis wanneer sy op haar kwesbaarste is en in haar nietigheid voor Gods aangesig staan, ongekende geloofskragte ontlaai wat haar in staat stel om die buitengewone eise van die daaglikse lewe te deurstaan. Gestroop van aardse rykdom, bedreig deur fisiese aanslae teen haar veiligheid, soms ook gestroop van aardse sekuriteit, bied haar wete van eie onmag en afhanklikheid van God die basis van sekerheid om in die binneland van Afrika te kan oorleef. Dít was waarskynlik een van die belangrikste dryfvere vir Johannes Petrus Venter om sy skoonmoeder se teologiese worstelingsdiskoers te publiseer - soos sy, was daar talle ander geestelike worstelaars op die limiete vir wie die daaglikse lewensstryd bykans bomenslike geestesinspanning en geloofskrag geverg het.

Die huidige opbloei van die Oosterse mistiek, die inslag van transendentale meditasie en 'n hunkering na die mistieke ervaring buite die gereformeerde belydenis om, noodsaak 'n skerp en kritiese blik op die aard en betekenis van die gereformeerde vroomheidsdenke - 'n legitieme eksperiment vir hulle wat daagliks uit die geloof wil leef. 


\section{Endnotas}

${ }^{1}$ Volgens die titelblad van die werk, uitgegee op versoek van haar skoonseun, Johannes Petrus Venter van Buffels Vallei, Hantam, distrik Colesberg. Hy was getroud met haar dogter Lasya Sophia (gedoop 10 September 1786).

${ }^{2}$ Aan die einde van die werk skryf ene J D Ackerman dat hy vir die oorskryf van dié werk verantwoordelik was en die teks van skryffoute gesuiwer het. Dié nota is gedateer 1830: "Ik twijfel niet of dit boek of andere dergelijke geschriften die in dit boek zijn geplaatst liefhebbers zullen vinden. De zaken die hierin voorkomen zijn gewigtig, de wijze van voorstel aangenaam, de stijl zeldzaam, en zeer bekwaam om de zaken voor het begrip vatbaar te maken, en in het gemoed der menschen in te doen dringen. Tegen schrijffouten heb ik zoo veel doenlijk gewaakt, en aan dit overschrijven geen moeite gespaard; de schrijffouten verbeterd. Ontvang het dan met zulk een hart als het $u$ wordt aangeboden, en gebruik het ten uwe nutte" (op 200).

${ }^{3}$ Dogter van Giullaume Nel van Rouaan, oorlede c 1785.

${ }^{4}$ Hy hertrou later met Cornelia Smit.

${ }^{5}$ Sy drie broers Andries, Tjaart en Johannes Petrus het waarskynlik vóór hom na dié geweste verhuis.

${ }^{6}$ Volgens D Moodie (in Van der Walt 1989:45) het 'n rapport van 15 November 1779 gelui dat die veldsersant op Sneeuberg, Carel Van der Merwe, op die 13de van die maand gerapporteer het dat Tjaart van der Walt, Nicolaas van der Walt en Johannes Petrus van der Walt uit Sneeuberg na Renosterberg, in die hart van Boesmanland, waar hulle voorheen woonagtig was, verhuis het. Ook A van Jaarsveld berig op 15 November 1779 dat die drie Van der Walt-broers - "goeie vegters, maar mense wat veel gedoen het om die Boesmans te versoen" - saam met ' $n$ paar ander boere uit die Sneeuberg na Renosterberg in die hartjie van Boesmanland, waar hulle al voorheen 'n keer gewoon het, verhuis het (Van der Walt 1989:46). Volgens 'n brief van Tjaart van der Walt aan sy broers Nicolaas en Johannes was dit veiliger daar teen die Boesmanaanvalle. Op 25 Augustus van dieselfde jaar rapporteer veldsersant Van der Merwe weer dat skade deur die Boesmans agter Renosterberg aangerig is, dat Johannes van der Walt se werkosse gesteel is, dat 'n kommando op die been gebring is wat 32 rowers gedood het, en dat $\mathrm{H}$ (Hendrik) van der Walt ook skape verloor het. Op die plaas van Johannes van der Walt is twee jong Hottentotte gedood en 60 skape uit die kraal verwyder.

${ }^{7}$ Hy was die swaer van Hester Venter en is op 21-jarige ouderdom op Tulbagh (op 21 Oktober 1770) met Alida Johanna Venter, haar suster, getroud.

${ }^{8}$ Die woonomstandighede waaronder Hester Venter haar vir ' $n$ beduidende deel van haar lewe teen die tweede helfte van die 18de eeu bevind het, het waarskynlik min verskil van die tipiese wonings van die gemiddelde trekboer-pioniers. Die huise van die nomadiese trekboere het van hul primitiewe lewensomstandighede getuig. Terwyl die Kapenaars aan ruim en gerieflike woonhuise gewoond was, was dié van die plattelandse veeboer-pioniers "niet dan rampsalige schuuren" (Van der Merwe 1938:61). Die huise het meestal uit net twee vertrekke bestaan. Een het as sitkamer, eetkamer en kombuis gedien. Die ander is as slaapkamer vir die gesin en as pakkamer gebruik. Op die limiete is eenvertrek-huisies algemeen aangetref. In 1778 vertel O G de Wet dat die huise in die Sneeuberge "meest allen bestaan in een enkeld laag gemuurd vertrek, zonder afzonderingen zijnde met een zoort van grof riet ondigt gedekt, welk vetrek tevens tot koorschuur en berging van andere goederen is dienende" (Van der Merwe 1938:208). Swellengrebel praat van "deze schuren, die kwalijk 40 voeten lang en 15 breed waren" en "hielden op sommige plaatsen twee tot drie huisgezinnen met hunne kinderen huis" (Van der Merwe 1938:212). Barrow (1806 II:85) beskryf die huise van die pioniers as "miserable hovels in which the graziers live", synde "pictures of want and wretchedness." Dit bestaan uit "( $f$ )our low mudwalls, with a couple of square holes to admit the light, and a door of wicker-work, a few crooked poles to support a thatch of rushes, slovenly spread over them" en wat dien "for the dwelling of many a peasant whose stock 


\section{Bevinding en geestelike verlating op die limiete}

consists of several thousand sheep and as many hundred head of cattle." Dié swak behuising van die trekboere was hoofsaaklik toe te skryf aan die hoë graad van mobiliteit wat hulle gehandhaaf het.

${ }^{9}$ D Moodie (in Van der Walt (1989:44) maak melding van 'n rapport gedateer 1779 waarin veldsersant Carel van der Merwe aan die landdros van Stellenbosch aangaande die broers van der Walt rapporteer dat Johannes van der Walt en Piet Venter saam met ander boere van hul plase moes vlug vanweë die Boesman-aanslag. Die aanvalle word beskryf as "violent murders and the robberies of the socalled Bushmen Hottentotts." Hy voeg by: "(T)hey break in daily more and more with furious pillaging as follows:from Hendrik and Johannes and from Nicolas van der Walt, 23 draught oxen." Elders meld die verslag dat vyf boere verplig was om te vlug, onder andere Johannes en Nicolaas van der Walt."

${ }^{10}$ Vir die tydperk Julie 1786 tot Desember 1788 rapporteer Woeke dat skade ten bedrae van 92000 riksdaalders deur die Boesmans aangerig is. Hulle het 107 veewagters vermoor en 6 299 beeste en 17970 kleinvee gebuit (Raum 1986:876).

${ }^{11} \mathrm{Hy}$ is op 28.02.1768 met Hester Venter se suster, Anna Martha Venter (gebore 26.01.1750, oorlede 10.06.1785) getroud.

${ }^{12}$ Teen die einde van die $18 d e$ eeu was die tekens dus reeds daar van ' $n$ onvermydelike skeiding van weë tussen die vrysinnige lewensbeskouings onder die meer akademies ontwikkelde burgery van die Kaap en die grensboere wat aan die grondslae van die Nadere Reformasie met sy sterk klem op die verbondsteologie vasgehou het (Raath 2002:44). Sien ook Schoeman $(1997: 123,124$.

${ }^{13}$ In die literatuur van die gereformeerde piëtisme kom die gedagte van 'n absolute moment in die Christelike eksistensie, 'n "uur der minne" of "stondetjie der minne" waarin alle beslissings vir tyd en ewigheid plaasvind, deurlopend na vore. Alexander Comrie (1706-74) $(1844, \mathrm{l}: 71)$ is een van die sterkste eksponente van dié gedagte. Volgens Comrie "(wordt) dat Geloof ... niet door studie, noch door redekaveling verkregen, maar door de onmiddelijke werking van God ..." (Comrie 1844, I:71). Dié "tijd der minne" is die moment van vereniging tussen Christus en die uitverkorenes: "Gij ziet derhalve, mijne Geliefden, dat wij van de waarachtige vereeniging, die getroffen wordt tusschen Christus en de uitverkorenen, (die door Hem zalig zullen worden) in den tijd der minne, spreken moet" (Comrie 1844, II:270). Die geloof word in dié stonde deur Christus in hul harte gewek: "Thans dienen wij van de wederzijdsche vereeniging, welke in den tijd der minne geschied, eenigzins nader te spreken. Ofschoon, mijne Geliefden, de uitverkorenen in Christus Jezus, door het onveranderlijk praedestinatie... dood in zonden en misdaden; en blijven alzoo, tot dat in Christus zich door den $\mathrm{h}$. geest met hun vereenigt, en Hij het geloof in hunne harten werkt, waar door zij met Hem vereenigd worden in hunne krachtdadige roeping"( Comrie 1844, II:269). In die "tyd der minne" word die uitverkorenes met Christus verenig: "Wij moeten den aanvang van deze vereeniging beschouwen, zoo als dezelve, zonder ons toedoen, begonnen wordt van de zijde van Christus, zich met den uitverkorenen zondaar vereenigende door den $\mathrm{h}$. geest, die als de eerste band, of vinculum unionis, (band van vereeniging) moet aangemerkt worden; dewijl God en Christus, in alle werking omtrent de schepselen, als de eerste oorzaak, den voorrang moeten hebben" (Comrie 1844, II:270-1). Bernardus Smijtegelt (1857:278) verwoord die ingrype van God met die oproep: "Gaat dikwijls zoo naar de kerk / met dat gebed / ach was het nu voor mij het uurtje der minne / het stondetjie van genade!"

${ }^{14}$ Die volle titel is Het Gekrookte Riet, of Honderd-Vijf-En-Veertig Predikatien over Mattheus XII:20, 21. Waarin een ZWAK- en KLEINGELOOVIG Christen opgewekt en bestierd wordt om op den HEERE JEZUS te hopen; mitsgaders verscheidene gevallen en zwarigheden van het gemoed worden opgelost en beantwoord, tot derzulker vertroosting en aanmoediging, om met blijdschap, al strijdende, den weg des geloofs naar den Hemel te bewandelen, en aan de eeuwige gelukzaligheid te zijner tijd deel te krijgen. Smijtegelt se Het Gekrookte Riet is tiperend van die bevindelike mistiek. Veral sy behandeling van Hooglied in dié werk lei daartoe dat die teks spoedig uit die gesigveld verdwyn en die prediking oorgaan tot "eene tot in de vezelen beschreven zielsanalyse"; "(i)n de vereniging van de afgematte en schreiende 
ziel met God vindt Smytegelt's prediking zijn grootste innigheid en diepste toespitsing" (Brienen 1981:128).

${ }^{15}$ By Lodensteyn kom daar in sy Uytspanningen geestelike minneliedjies voor waarin ' $n$ minder gesonde mistiek vervat is - die aandoeninge van die aardse liefde word op die verhouding tussen Christus en sy bruid, die siel, oorgedra, byvoorbeeld "Jesus met sijn Bruyd in Twee-spraak" (Lodensteyn 1721:103) en "Lied Der Minne Tusschen Emmanuel en Salumith" (Lodensteyn 1721:104-9). By Lodensteyn kom die drie kenmerke van die gereformeerde piëtisme sterk na vore:'n strewe na reformasie van die lewe, 'n reaksie teen die dogmatisme en ' $n$ liefde vir die mistiek. Die liedere van Lodensteyn was ook bedoel om in die kringe van vromes gesing te word: "Aan den anderen kant waren zijne liederen bestemd, om te worden gezongen in den kring van vromen. Dit mocht, volgens de meening van den dichter, niet op dezelve wijze als met wereldsche liederen geschieden" (Proost 1880:97-8). Met die oog op die bevindelike waarde van sy liedere gee Lodensteyn "eenig onderrigt" hoe die sang moet verloop: "'t Herte dient tot den Sang opgeligt door eenige suchtingen of gebeden tot den Heere, "t sy dan eensame of gesellige, gestelde of uytgeschotene" (Lodensteyn 1721:voorrede 2-6). Omdat sulke byeenkomste van Christene tot stigting moes wees, is hul deur die outeur aangemoedig om na elke lied met vrymoedigheid "voort te brengen 't geen de $\mathrm{H}$. Godheyd in 't singen hem door den Geest geopenbaart of doen gevoelen heeft" (Lodensteyn 1721:voorrede).

${ }^{16}$ Van Zijl (1991:201-202) stel die invloed van die outeurs van die Nadere Reformasie aan die Kaap soos volg: "Alhoewel die 'oude schrijvers' in mindere of meerdere mate van die reformatoriese model weggeskuif het in hul beklemtonings, het hul gedrukte boodskap, ten spyte van die praktiese omstandighede van destyds, tot die gereformeerde lidmaat gespreek. Dit blyk dus dat die Nederduitse Gereformeerde preek- en oordenkingsbundels méér as die prediking en pastorale besoeke bygedra het tot ' $n$ omlyning van die singewing aan die gereformeerde belydenis in die lewe van die lidmate."

${ }^{17}$ Waarskynlik haar swaer Nicolaas Van der Walt (gedoop 13 Februarie 1757), getroud op 13 September 1778 met Maria Jacoba Coetsee (wat op 13 Februarie 1785 gedoop is), se dogter.

${ }^{18}$ In die kringe van die gereformeerde vroomheidsteologie het die bevinding as instrument om die gelowige na Christus te dryf, dikwels in die literatuur ter sprake gekom. In sy A.B.C. des Geloofs het A Comrie $(1754: 1,3)$ hom soos volg oor geloof en bevinding uitgelaat: "Maar sonder Geloove is het onmogelyk [Gode] te behaagen, geeven grondt tot veel naukeurige ondersoeking van syne Siele/aangaande den staat en werksaamheidder Siele in 't verborgen voor Godt" en "... want dan souden wy sien/hoe een en het zelfde Geloove onder andere benamingen voorkomt; en soekende en heilbegerigen / schoon deese en geene saaken onder sekere benamingen opgesloten niet ondervindende / niet voor het hoofde stooten en slingeren / als sy de zielswerksaamheden / onder een' andere benaminge begrepen / ondervonden: De eene gelovige sal veel van het Geloove hebben onder de benaminge van Vertrouwen, maar een ander sal meer werksaam zyn in 't vluchten tot Jezus: beide zyn werksaamheden van het selfde Geloove; en daarom heeft de een den anderen niet te verdenken noch hardt te handelen."

\footnotetext{
19 "Aan D. Samuel Doreslaar op sijne Bedenckingen daar over 19 Maart 1652."

20 'n Lied oor Openbaring 19:6, 7, 8.
}

${ }^{21}$ By die grondleggers van die gereformeerde piëtisme, teen die middel van die $17 \mathrm{de}$ eeu, is die gereformeerde bruidsmistiek reeds aanwesig. In die gedigte van die Enkhuizense digter Claes Jacobsz Wits (1599-1669), in sy bundel Stichtelycke Bedenckinghe, Onledighe Ledigheydt, Stichtelycke Tijd-kortinge. Vertoont door Geestelicke Gesanghen (Wits 1645), word 'n groot gedeelte aan gesprekke tussen Christus en sy kerk gewy, byvoorbeeld die lied van die Bruid uit die "Liefdens Gesang, Uit het Vyfde Capittel van het Hooge Liedt Salomons" op die wysie van "O! Kersnacht schoonder, ens" (Wits 1645:64-66): 


\section{Bevinding en geestelike verlating op die limiete}

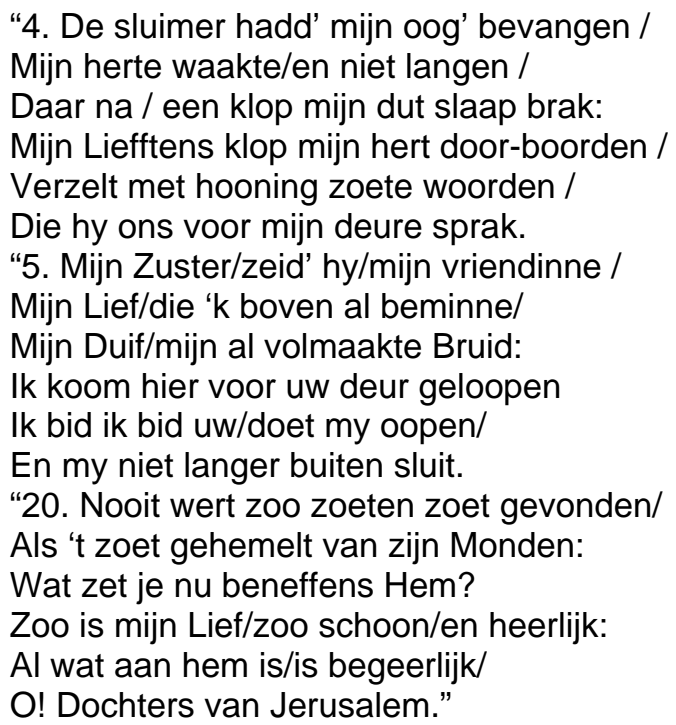

Jonckheer M vander Merwede Heere van Clootwijk, in sy Geestelyke Minne-Vlammen (1653:1-27) handel met die Hooglied van Salomo. Hoofstuk een:

"Bruyd.

Geef my een kus, neyg my u mond,

Gy die my aen u ziel verbond,

$U$ Min is beter als de wijn,

Haer die krank van u liefde zijn.

Vierde hoofstuk:

"Bruydegom.

Hoe schoon ziit gy, miin Herderin!

Hoe liefliik is u soete min!

$\mathrm{U}$ duyven-oogskens stadig vonxkens speyten,

$U$ hair is als een kudde jonge Geyten.

Agste hoofstuk:
"Bruyd.
Kom dan haest'liik aan getreden,
Spoed u wakker als een Rhee,
Steld miin minne-lust te vreden,
"k Ben tot uwe kusjes ree."

Latere eksponente van die gereformeerde vroomheidsteologie, soos Bernardus Smijtegelt, huldig ook 'n sterk inslag van die bruidsmistiek: "Als God de ziele omhelst, dan komt hij een weinig nader / en hij zegt / laat Ik u een kus van mijnen mond geven / mijne genegenheid is tot $U$ / en de Koning neemt de ziele bij de hand / en Hij leidt ze in zijne binnekameren.

Hooglied 1:4" (Smijtegelt 1857:65). Kyk ook Coenraad Mel, "De Laatste Bede van Christus Bruid" in sy De Laatste Woorden der Stervenden (Mel 1860:360-373).

\footnotetext{
${ }^{22}$ Veral by A Comrie tree die vereniging van die gelowige siel met Christus sterk op die voorgrond. Volgens Comrie (1844, II:260-276) is die nuwe lewe in Christus slegs moontlik indien gefundeer in die voorafgaande vereniging met Christus. Dié vereniging is ' $n$ baie noue, verborge, allerwaaragtigste en onskeibare betrekking tussen Christus en die gelowige, waarin verskeie stappe van eenwording te bespeur is (kyk ook Graafland 1961:218-237).

${ }^{23}$ Voetius se méér uitgebreide formulering van die doel van die verlating deur God gestuur lui "dat de geloovige beproefd en aan zich zelven en anderen des te beter bekend worde; opdat in hem de begeerte naar de genade en de heerlijkheid steeds meer moge worden versterkt, opdat de verborgene zonden ontdekt en de toekomende voorkomen worden, opdat
} 
teederheid van geweten en eene juiste en nauwkeurige opmerking omtrent zijne wegen worden geleerd, opdat hij ledig en arm van geest worde, opdat hij eenen afkeer van deze wereld en het pelgrimsleven krijge, opdat hij aan de aardsche en uiterlijke vreugde en vertroosting gespeend worde, opdat hij leere met trane gespijsd te worden, als zijnde de eenige lekkernij der vertroosting, wanneer de Vertrooster niet tegenwoordig is, opdat hij zijnen God zoveel te vaster aanhange" (37).

${ }^{24}$ Hierdie element van die geestelike verlating word deur Bernardus Smijtegelt sterk aan die orde gestel: "Zij raken den troost kwijt / die ze hadden; dien invloed / die verkwikking / dat zoete / dat ze hadden aan het Avondmaal / in het lezen en in het bidden / dat wordt opgeschort:ga ik voorwaarts, Hij is er niet als ik roep:de Heere houdt zich als doof / de lampe Gods is zoo niet meer brandende over hunne tente ..." (Smijtegelt 1858:163). Ook die bekende skrywer uit die tyd van die gereformeerde piëtisme, Coenraad Mel, in sy Heraut der Eeuwigheid, skenk aandag aan geestelike verlating in die tweede leerede onder die tema van "Het Verlangen van den Propheet Elias, naar den Dood, het Leven Moede zijnde". In die gebed om krag teen die geestelike verlating doen hy 'n beroep op die beloftes van God: "Eerder zoude hemel en aarde vergaan, als dat de geringste van uwe genadige beloften onvervuld zoude blijven: Gij zijt doch onze Vader; van ouds af is dit uw naam en uwe kracht:Ja! Eerder zoude eene moeder haar kind vergeten, en zich niet ontfermen over de zoon hares buik, als dat Gij uwe kinderen zoudt vergeten; want Gij hebt ze in uwe handpalmen gegraveerd. Laat ons doch niet moede en mat worden, onder de menigerlei verzoekingen der wereld, maar altoos gedenken, dat dit door allen eeuwen heen, het lot van uwe kinderen geweest is" (Mel 1863:16-28). Alhoewel Mel (1666-1733) 'n Duits-

gereformeerde teoloog was, is hy in Nederland opgelei en is sy werke aan die Kaap wyd gelees. Die inslag daarvan het duidelike trekke van die bevindelike mistiek getoon.

${ }^{25}$ Die geestelike inslag van Hester Venter se meditasies verteenwoordig in verskeie opsigte 'n "universaliseerbare" piëtistiese tendens onder die Dopper-trekboerpioniers. Die neerslag van die piëtistiese werke van die Nadere Reformasie in die afgeleë dele van die binneland verteenwoordig 'n algemene neiging tot verdieping in die sogenaamde piëtistiese "oude schrijvers" (Van Zijl 1991:228-275). Die geestelike inslag van hierdie Nederlandse piëtisme onder die grensboere is deur die trekbeweging na die binneland voortgedra (Raath 2002:1783; 2002a:76-119, 128-135, 132-135). Die invloed wat die werke van die Nadere Reformasie op die lewenspraktyk van die trekkers (wat grotendeels uit die Dopper-trekboerbeweging voortgekom het), was besonder groot (Raath 2001:908-958). Ook die besondere nalewing onder die Boerevroue, wat vir korter of langer tye in die afgeleë dele van die binneland vertoef het (Raath 2003:121-150) noop die volgende konklusies:eerstens, dat die belangstelling in die Nederlandse piëtistiese literatuur onder die grensboere nie 'n geïsoleerde verskynsel was nie, en tweedens, dat die piëtisteise geloofsbelewing (waarskynlik met wisselende grade van intensiteit) ' $n$ integrale deel van die Dopper-grensboere se beoefening van die geloof, eerder as 'n abstrakte supralapsariese Calvinisme was.

\section{Literatuurverwysings}

Barrow, J 1806. Travels into the interior of South Africa, Vol $1 \& 2,2^{\mathrm{e}} \mathrm{ed}$. London: T Cadell \& W Davies.

À Brakel, W [1700] 1713. Redelijke Godsdienst, Vol I. Rotterdam: Hendrik vanden Aak. (Eksemplaar: A W G Raath, Bloemfontein.)

Brienen, T 1978. Bevinding: Aard en funktie van de geloofsbelewing. Kampen: Kok. Brienen, T 1981. De Prediking van de Nadere Reformatie. Amsterdam: Ton Bolland. Comrie, A [1739] 1754. Het A.B.C. des Geloofs, of Verhandeling van de Benamingen des Saligmakenden Geloofs Volgens de Letteren van het Alphabeth. Leiden: Johannes Hasebroek. (Eksemplaar: A W G Raath, Bloemfontein.) 


\section{Bevinding en geestelike verlating op die limiete}

Comrie, A [1753] 1844. Stellige en Praktikale Verklaring van den Heidelbergsche Catechismus, volgens de Leer en de Gronden der Reformatie ... , Vol 2. Nieuwe Uitgave. Minnertsga: J Bloemsma. (Eksemplaar: A W G Raath, Bloemfontein.)

De Villiers, C C \& Pama, C 1981. Geslagsregisters van die ou Kaapse families, Vol 2. N-Z. Kaapstad: A A Balkema.

Godee Molsbergen, E C, 1916-1932. Reizen in Zuid-Afrika in de Hollandsche Tijd, dle I-IV. S' Gravenhage: Nijhoff. (Linschoten-vereeniging, no $11,12,20,35$.

Hoornbeeck, J [1646] 1898. Eene disputatie van Gisbertus Voetius .... Voortgezit door Johannes Hoornbeeck. S I: Het Traktaat-Genootschap "Filippus". Utrecht: Lambert Roech.

Kaapse Argiefbewaarplek (KAB) en N G Kerkargief (KKA). Ongepubliseerde bronne: KAB, BO24. KAB, C321. KAB, LRL 20.KAB, LRL 21. KAB, LRL 22. KAB, LRL 35. KAB, LRL 78a. KKA, G4 3/2.

Mel, C 1863. De Heraut der Eeuwigheid: Of Leeredenen van het Dood, de Opstanding der Dooden het Laatste Oordeel, Helle en Hemel; ... Nieuwe Uitgave. Nijkerk: I J Malga. (Eksemplaar: A W G Raath, Bloemfontein.)

Mel, C 1860. De Laatste Woorden der Stervenden; vertoond in LVIII Predikatien, Vol I. Nieuwe Uitgave. Nijkerk : I J Malga. (Eksemplaar: A W G Raath, Bloemfontein.)

Mossop, E E 1947. Lives of the early Krugers told in a revised geneological table. Argiefjaarboek vir Suid-Afrikaanse geskiedenis. Kaapstad: Staatsdrukker.

Murray, J 1877. Some characteristics of our fellow colonists, in Cape Monthly Magazine.

Proost, P 1880. Jodocus van Lodenstein. Amsterdam: J Brandt \& Zoon.

Raath, A W G 2001. Die teologiese agtergronde van die Voortrekkergelofte (1838), HTS 57(3\&4), 908-958.

Raath, A W G 2002. Volk en verbond, Reformerend die millenium, in Ons Calvinistiese erfenis en roeping, 1652-2002, 17-83. Bloemfontein: Vereniging vir Christelike Hoër Onderwys.

Raath, A W G 2002a. The Dutch second reformation on the frontier: Wilhelmus à Brakel (1635-1711) and the relationship between the church and political authorities in the Transvaal Settlements in South Africa (1845-1860). Studia Historiae Ecclesiasticae 28(1), 76-119.

Raath, A W G 2002b. Ons geestelike erfenis, 1652-2002. Almanak \& Bybelse Dagboek 99, 128-135.

Raath, A W G 2003. Eensaam in die Voortrekkergemeenskap: Askese en geloofsbelewing in die teologie van die Voortrekkervrou Susanna Smit (17991836). HTS 59(1), 121-150.

Raum, O F 1986. Woeke, Moritz Hermann Otto, Suid-Afrikaanse Biografiese Woordeboek, Vol II, 786-787. Pretoria: Raad vir Geesteswetenskaplike Navorsing.

Schoeman, K 1997. Dogter van Sion: Machtelt Smit en die 18de eeuse samelewing aan die Kaap, 1749-1799. Kaapstad: Human \& Rousseau.

Sluyter, W [1680-82] 1838. Werken. Laatste druk. Nieuwe uitgave. Rotterdam: M Wijt \& Zonen.

Smijtegelt, B [1744] 1857. Een Woord op Zijn Tijd of Twee en Veertig Predikatien, ... Vol. I, Nieuwe Onveranderde Uitgave. Nijkerk: I J Malga. (Eksemplaar: A W G Raath, Bloemfontein.) 
Smijtegelt, B [1837] 1858. Maandagsche Katechisatiën, naar het beloop van den Heidelbergsche Kategismus, ... zijnde een Huis- en Handboek, tot Onderwijzing in de Gereformeerde Leer. Voorgesteld in Vragen en Antwoorden. Nieuwe Uitgave. Nijkerk: I J Malga. (Eksemplaar: A W G Raath, Bloemfontein.)

Smijtegelt, B [1744] 1860. Het Gekrookte Riet, of Honderd-Vijf-en-Veertig Predikatien over Mattheus XII:20, 21. Waarin een ZWAK- en KLEINGELOOVIG CHRISTEN opgewekt en bestierd wordt om op den HEERE JEZUS te hopen; mitsgaders verscheidene gevallen en zwarigheden van het gemoed werden opgelost ... Vol. I. Nieuwe onveranderde uitgave. $2^{\mathrm{e}}$ druk. Nijkerk: I J Malga.

Spoelstra, B 1963. Die "Doppers" in Suid-Afrika 1760-1899. Kaapstad: Nasionale Boekhandel.

Spoelstra, C 1907. Bouwstoffen voor de Geschiedenis der NederduitschGereformeerde Kerken in Zuid-Afrika, Vol II. Amsterdam: HollandschAfrikaansche Uitgevers-Maatschappij.

Troelstra, S H 1976. Geen enkel beeld: Mystieke weg, deprojectie en individuatie bij San Juan de la Cruz. Amsterdam.

Van der Merwede, M 1653. Geestelyke Minnevlammen. 'sGravenhage: Isaac Burghoorn. (Eksemplaar: A W G Raath, Bloemfontein.)

Van der Merwe, P J 1937. Die noordwaartse beweging van die boere voor die Groot Trek (1770-1842). Den Haag: W P van Stockum \& Zoon.

Van der Merwe, P J 1938. Die trekboer in die geskiedenis van die Kaapkolonie (1657-1842). Kaapstad: Nasionale Pers.

Van der Merwe, P J 1940. De Kafferoorlog van 1793. Kaapstad: Nasionale Pers.

Van der Merwe, P J 1945. Trek: Studies oor die mobiliteit van die pioniersbevolking aan die Kaap. Kaapstad: Nasionale Boekhandel.

Van der Walt, C M et al. 1989. Die familie van der Walt in Suid-Afrika. Pretoria: Raad vir Geesteswetenskaplike Navorsing.

Van Lieburg, F A 1991. Levens van vromen: Gereformeerde piëtisme in de achttiende eeuw. Kampen: De Groot Goudriaan.

Van Lodensteyn, J [1676] 1721. Uytspanningen, Behelsende eenige Stichtelyke Liederen, en ander Gedichten: Verdeeld in vier Deelen: Met een Aanhangsel. $8^{\mathrm{e}}$ druk. Amsterdam: Weduwee Barent Visscher. (Eksemplaar Theo du Plessis, Bloemfontein.)

Proost, P 1880. Jodocus van Lodenstein. Amsterdam: J Brandt \& Zoon.

Van Ruler, A A 1971. Theologisch Werk, Vol 3. Nijkerk: Callenbach.

Venter, H 1853. De Ondervindelijke Bekeeringsweg. Kaapstad: Van De Sandt De Villiers. (Eksemplaar: A W G Raath, Bloemfontein.)

Voetius, G [1646] 1898. Eene disputatie over Geestelijke Verlatingen ... Naar den eersten druk van Lambert Roeck, Boekdrukker te Utrecht, Anno 1646, overgebracht in onze tegenwoordige Nederlandsche taal. S I: Het TraktaatGenootschap "Filippus". (Eksemplaar: A W G Raath, Bloemfontein.)

Von Meyer, W 1843. Reisen in Süd-Afrika während der Jahre 1840 und 1841. Hamburg: Verlag von J B Grie.

Wits, J C 1645. Stichtelijcke Bedenkinge, Ontledighe Ledigheydt, Stichtelycke Tijdkortinge: Vertoont door Geestelicke Gesangen. Amsterdam: Hendrik vander Putte. (Eksemplaar:A W G Raath, Bloemfontein.)

Van Zijl, W J 1991. Van skeepskis na wakis tot boekrak. Kaapstad: Lux Verbi. 